\title{
Synthesis of the Pyrazolo[4,3-e][1,2,4]triazine Family of Natural Products: Nostocine A, Fluviol A and Pseudoiodinine
}

\author{
T. Ross Kelly, ${ }^{*}$ Eric L. Elliott, Rimma Lebedev, and Jaione Pagalday. \\ E. F. Merkert Chemistry Center, Boston College, Chestnut Hill, Massachusetts 02467
}

Supporting Information

ross.kelly@bc.edu

\section{Table of Contents}

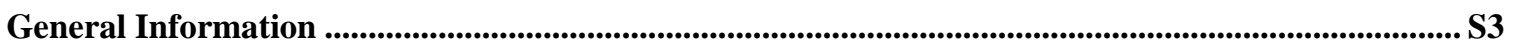

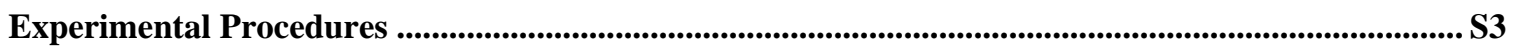

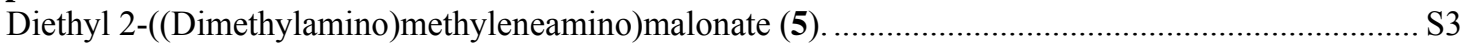

Ethyl 1,4,5,6-Tetrahydro-6-oxo-1,2,4-triazine-5-carboxylate (6)..................................................... S3

Ethyl 1,6-Dihydro-6-oxo-1,2,4-triazine-5-carboxylate (7) ............................................................... S4

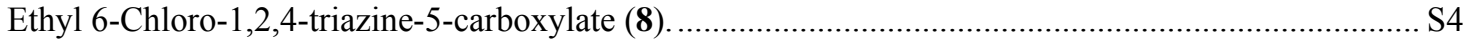

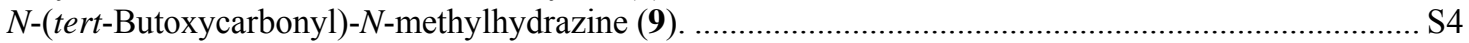

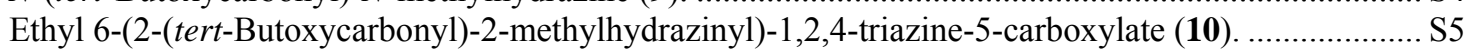

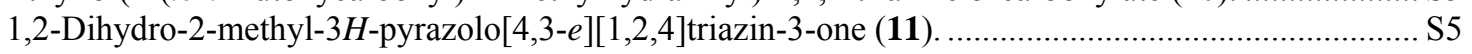

3-Methoxy-2-methyl-2H-pyrazolo[4,3-e][1,2,4] triazine (12) ........................................................... S5

Ethyl 6-(2-(tert-Butoxycarbonyl)hydrazinyl)-1,2,4-triazine-5-carboxylate (14)................................. S6

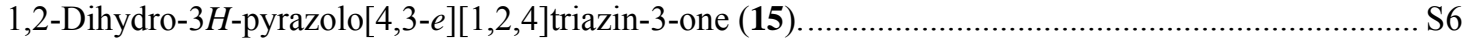

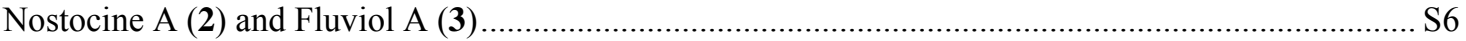

Methylation of Fluviol A (3) to Give Pseudoiodinine Following the Procedure of Lindner and Schaden.

1,2-Dihydro-1-methyl-3H-pyrazolo[4,3-e][1,2,4]triazin-3-one (21) ........................................... S8

3-Methoxy-1-methyl-1 H-pyrazolo[4,3-e][1,2,4] triazine (20).......................................................... S8

Methylation of Nostocine A (2) to Give Pseudoiodinine..................................................................... S8

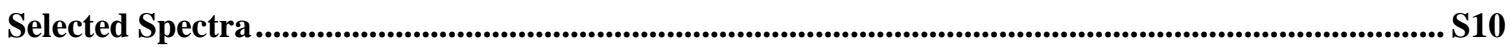

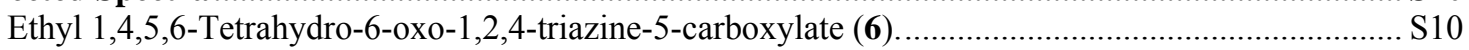

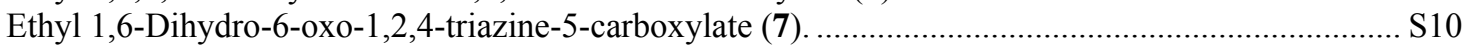

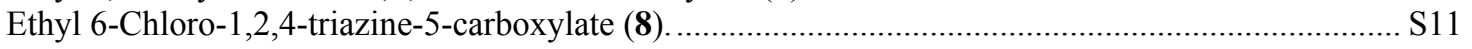

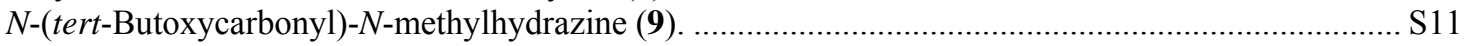

Ethyl 6-(2-(tert-Butoxycarbonyl)-2-methylhydrazinyl)-1,2,4-triazine-5-carboxylate (10). ................. S11

1,2-Dihydro-2-methyl-3H-pyrazolo[4,3-e][1,2,4]triazin-3-one (11) .............................................. S12

3-Methoxy-2-methyl-2H-pyrazolo[4,3-e][1,2,4]triazine (12)....................................................... S12

Ethyl 6-(2-(tert-Butoxycarbonyl)hydrazinyl)-1,2,4-triazine-5-carboxylate (14) ............................... S12 
1,2-Dihydro-3H-Pyrazolo[4,3-e][1,2,4]triazin-3-one (15)_............................................................ S13

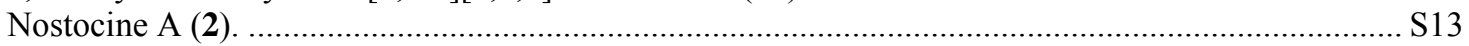

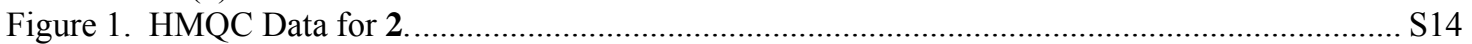

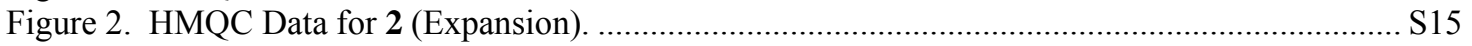

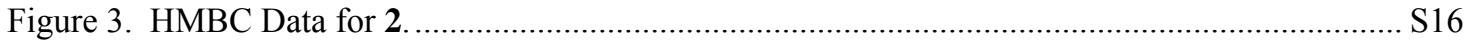

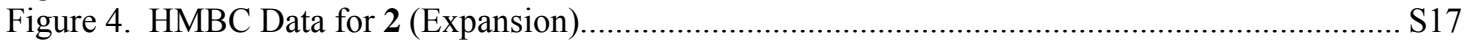

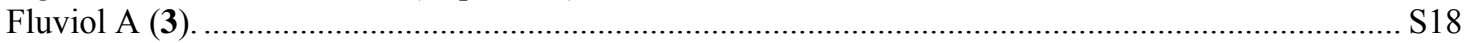

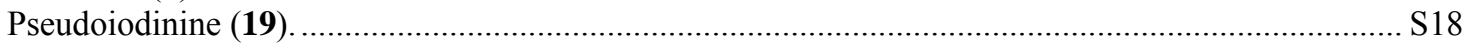

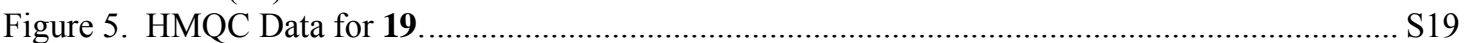

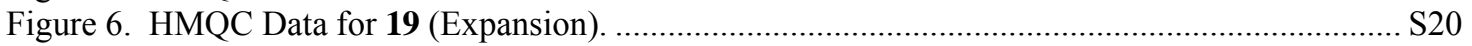

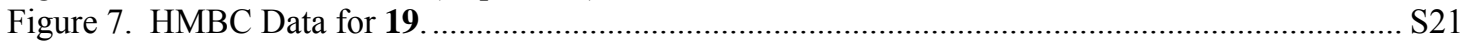

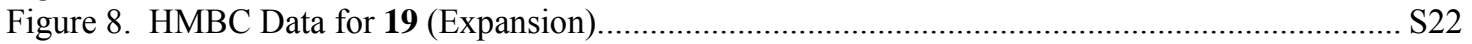

1,2-Dihydro-1-methyl-3H-pyrazolo[4,3-e][1,2,4]triazin-3-one (21) ............................................... S23

3-Methoxy-1-methyl-1H-pyrazolo[4,3-e][1,2,4] triazine (20)........................................................ S23

1,2-Dihydro-1,2-dimethyl-3H-pyrazolo[4,3-e][1,2,4]triazin-3-one (22) ........................................... S24

2,7-Dihydro-2,7-dimethyl-3H-pyrazolo[4,3-e][1,2,4]triazin-3-one (23) ........................................ S24 


\section{General Information}

${ }^{1} \mathrm{H}-$ and ${ }^{13} \mathrm{C}$ NMR spectra were recorded on a Varian Unity $300 \mathrm{MHz}$ spectrometer, Varian Gemini $400 \mathrm{MHz}$ spectrometer or a Varian Unity INOVA $500 \mathrm{MHz}$ spectrometer. The chemical shifts are reported relative to tetramethylsilane $(0.00 \mathrm{ppm})$ as the internal standard with the exception of spectra recorded in dichloromethane- $\mathrm{d}_{2}$ (DCM- $\left.\mathrm{d} 2\right)$, which used the solvent residual peak $(5.32 \mathrm{ppm})$. NOe difference, NOESY2D, HMBC and HMQC spectra were recorded on a Varian Unity INOVA $500 \mathrm{MHz}$ spectrometer using pulse field gradients. High-resolution mass spectra were obtained from the University of Illinois, Urbana-Champaign spectrometry facility. Infrared spectra were recorded using a Nicolet Avatar 360 FTIR. Uv-Vis spectra were recorded on an Agilent 8453 spectrometer. Melting points were obtained on a Fisher-Johns melting point apparatus and are uncorrected.

Acetonitrile $\left(\mathrm{CH}_{3} \mathrm{CN}\right)$, diethyl ether $\left(\mathrm{Et}_{2} \mathrm{O}\right)$ and dichloromethane $(\mathrm{DCM})$ were dried by passage through a column of activated alumina under a positive pressure of nitrogen. ${ }^{1}$ Absolute ethanol (EtOH) and anhydrous methanol $(\mathrm{MeOH})$ were purchased from Acros and used without further purification. Chloroform $\left(\mathrm{CHCl}_{3}\right)$ was purchased from Doe and Ingalls and contained $0.2 \% \mathrm{EtOH}$ as stabilizer. Ethyl acetate (EtOAc), hexanes, $\mathrm{CHCl}_{3}, \mathrm{MeOH}$, and $\mathrm{DCM}$ were distilled prior to use in chromatography. Phosphorus oxychloride $\left(\mathrm{POCl}_{3}\right)$ was distilled from sodium metal under an atmosphere of $\mathrm{Ar}$ and used within 4 weeks. All other reagents were purchased from either Aldrich or Acros and used as supplied. Unless otherwise noted, chromatographic separations were performed by standard flash chromatography techniques using reagent silica gel $(60 \AA)$ purchased from Bodman. Medium Pressure Liquid Chromatography (MPLC) was performed using a Biotage Horizon HPFCTM system with pre-packed KPsilica gel $(60 \AA)$ cartridges at 30 psi. Rotary evaporation was normally carried out at a pressure of ca 6 torr using a diaphragm vacuum pump.

\section{Experimental Procedures}

Diethyl 2-((Dimethylamino)methyleneamino)malonate (5). ${ }^{2}$

In a flame-dried, $1 \mathrm{~L}$ round-bottom flask under an atmosphere of $\mathrm{Ar}$, thin strips of pressed sodium metal $(5.65 \mathrm{~g}, 246 \mathrm{mmol})$ were added to ice-cold absolute EtOH $(300 \mathrm{~mL})$ over ca $5 \mathrm{~min}$. After the sodium was consumed (ca $30 \mathrm{~min})$, diethyl aminomalonate hydrochloride $(51.1 \mathrm{~g}, 246 \mathrm{mmol})$ was added in one portion. The flask was removed from the ice bath and stirred at ambient temperature for $15 \mathrm{~min}$. The volatiles were then removed by rotary evaporation and the crude residue was diluted with benzene ( 250 $\mathrm{mL})$. After addition of $N, N$-dimethylformamide dimethyl acetal $(45.0 \mathrm{~mL}, 317 \mathrm{mmol})$, the cloudy solution was heated at reflux for $15 \mathrm{~min}$. After standing at ambient temperature overnight, the resulting precipitate $(\mathrm{NaCl})$ was removed by filtration through a plug of packed Celite. Removal of the benzene by rotary evaporation, followed by addition of 1:1 (v/v) EtOAc:hexanes $(100 \mathrm{~mL})$ and subsequent evaporation yielded 5 as an off-white solid (50.6 g, 89\%). Mp 26-30 ${ }^{\circ} \mathrm{C}$. ${ }^{1} \mathrm{H}$ NMR $\left(300 \mathrm{MHz}, \mathrm{CDCl}_{3}, \delta\right): 1.28$ (t, $J=$ $7.2 \mathrm{~Hz}, 6 \mathrm{H}), 2.93$ (s, 6H), 4.23 (q, J=7.2 Hz, 4H), 4.47 (s, 1H), 7.44 (s, 1H).

\section{Ethyl 1,4,5,6-Tetrahydro-6-oxo-1,2,4-triazine-5-carboxylate (6). ${ }^{3}$}

In a flame-dried, 2-neck round-bottom flask under an atmosphere of Ar, amidine 5 (47.0 g, 204 mmol) was stirred in absolute EtOH $(300 \mathrm{~mL})$. The suspension was heated to reflux (all of the amidine was now dissolved). To the refluxing solution was added a solution of anhydrous hydrazine $(8.20 \mathrm{~mL}, 260$ $\mathrm{mmol})$ in absolute EtOH $(300 \mathrm{~mL})$ dropwise via an addition funnel over ca $1 \mathrm{~h}$. The reaction was heated at reflux for an additional $30 \mathrm{~min}$ and then cooled in an ice-water bath for $1 \mathrm{~h}$. Crude 5-hydrazinocarbonyl1,2,5,6-tetrahydro-6-oxo-1,2,4-triazine ${ }^{2 \mathrm{a}}(7.4 \mathrm{~g}, 23 \%)$ was removed by filtration. The filtrate was evaporated to dryness and the resulting oily orange solid was mostly dissolved in 1:4 (v/v) MeOH: EtOAc

\footnotetext{
${ }^{1}$ Pangborn, A. B.; Giardello, M. A.; Grubbs, R. H.; Rosen, R. K.; Timmers, F. J. Organometallics 1996, 15, 1518-1520.

2 a) Smodiš, J.; Zupet, R.; Petrič, A.; Stanovnik, B.; Tišler, M. Heterocycles 1990, 30, 393-405. b) The procedure to make 5 was adapted slightly from the one presented in the paper.

${ }^{3}$ Procedure adapted from the synthesis of 5-hydrazinocarbonyl-1,2,5,6-tetrahydro-6-oxo-1,2,4-triazine reported in ref. $2 \mathrm{a}$.
} 
(750 mL). The suspension was filtered through a plug of $\mathrm{Al}_{2} \mathrm{O}_{3}$ (Brockmann III, $100 \mathrm{~g}$ ) and the plug was washed with 1:9 (v/v) MeOH: EtOAc $(1 \mathrm{~L})$. Rotary evaporation of the combined filtrate and wash yielded an oily yellow solid $(24.0 \mathrm{~g})$. The crude material was left to stand with EtOAc $(400 \mathrm{~mL})$ for $1 \mathrm{~h}$ and the resulting off-white precipitate was collected by filtration to afford $6(15.1 \mathrm{~g}, 43 \%)$. Mp ${ }^{4} 128-131^{\circ} \mathrm{C} .{ }^{1} \mathrm{H}$ NMR (400 MHz, DMSO-d6, $\delta): 1.19$ (t, $J=7.2 \mathrm{~Hz}, 3 \mathrm{H}), 4.13$ (q, $J=7.2 \mathrm{~Hz}, 2 \mathrm{H}), 4.54$ (d, $J=1.6 \mathrm{~Hz}, 1 \mathrm{H}$ ), 6.96 (d, $J=4 \mathrm{~Hz}, 1 \mathrm{H}), 7.55$ (bs, 1H), 10.4 (bs, 1H). ${ }^{13} \mathrm{C}$ NMR (100 MHz, DMSO-d6, $\delta$ ): 14.0, 56.2, 61.3, 136.6, 156.5, 168.4. IR (KBr) $\left(\mathrm{cm}^{-1}\right): 3340,3192,3051,2924,1748,1672,1646,1505$. UV (EtOH) $\lambda_{\max }$ ( $\log \varepsilon): 223$ (3.3), 278 (3.3). HRMS-ESI (m/z): $[\mathrm{M}+\mathrm{H}]^{+}$calcd for $\mathrm{C}_{6} \mathrm{H}_{10} \mathrm{~N}_{3} \mathrm{O}_{3}, 172.0722$; found, 172.0721.

\section{Ethyl 1,6-Dihydro-6-oxo-1,2,4-triazine-5-carboxylate (7).}

In a flame-dried, $1 \mathrm{~L}$ round-bottom flask under an atmosphere of Ar, dihydrotriazone 6 (15.1 g, $88.2 \mathrm{mmol})$ was dissolved in absolute $\mathrm{EtOH}(400 \mathrm{~mL})$. Iodobenzene diacetate $(29.3 \mathrm{~g}, 91.1 \mathrm{mmol})$ was added in one portion and the reaction was stirred at ambient temperature for $2 \mathrm{~h}$. The volatiles were removed by rotary evaporation. The resulting oil was dissolved in $\mathrm{CHCl}_{3}(25 \mathrm{~mL})$ and purified by column chromatography using $\mathrm{SiO}_{2}$ gel $(4 \times 16 \mathrm{~cm})$ eluting first with 1:2 (v/v) EtOAc:hexanes until all of the iodobenzene was removed and then with 1:1 (v/v) EtOAc:hexanes, to yield 7 as a yellow powder $(10.4 \mathrm{~g}$, 70\%). Mp 94-96 ${ }^{\circ} \mathrm{C} .{ }^{1} \mathrm{H}$ NMR $\left(400 \mathrm{MHz}, \mathrm{CDCl}_{3}, \delta\right): 1.44$ (t, $\left.J=7.2 \mathrm{~Hz}, 3 \mathrm{H}\right), 4.51$ (q, $\left.J=7.2 \mathrm{~Hz}, 2 \mathrm{H}\right)$, $8.42(\mathrm{~s}, 1 \mathrm{H}), 12.12$ (bs, $1 \mathrm{H}) .{ }^{13} \mathrm{C} \mathrm{NMR}\left(100 \mathrm{MHz}, \mathrm{CDCl}_{3}, \delta\right): 13.9,63.0,141.4,153.0,157.9,161.5$. IR $(\mathrm{KBr})\left(\mathrm{cm}^{-1}\right): 3308,3097,3067,2986,1732,1673,1644,1579,1525 . \mathrm{UV}(\mathrm{EtOH}) \lambda_{\max }(\log \varepsilon): 220$ (3.7), 312 (3.4). HRMS-ESI (m/z): $[\mathrm{M}+\mathrm{H}]^{+}$calcd for $\mathrm{C}_{6} \mathrm{H}_{8} \mathrm{~N}_{3} \mathrm{O}_{3}, 170.0566$; found, 170.0572 .

\section{Ethyl 6-Chloro-1,2,4-triazine-5-carboxylate (8).}

In a flame-dried, $1 \mathrm{~L}$ round-bottom flask under an atmosphere of Ar, triazinone 7 (6.95 g, 41.1 mmol) and benzyltriethylammonium chloride $(18.8 \mathrm{~g}, 82.5 \mathrm{mmol})$ were dissolved in anhydrous $\mathrm{CH}_{3} \mathrm{CN}$ $(165 \mathrm{~mL}) . N, N$-Dimethylaniline $(6.25 \mathrm{~mL}, 49.3 \mathrm{~mL})$ was added, followed by addition of $\mathrm{POCl}_{3}(19.0 \mathrm{~mL}$, $204 \mathrm{mmol}$ ) in one portion. The flask was immediately lowered into an oil bath pre-heated to $120^{\circ} \mathrm{C}$. After $11 \mathrm{~min}$ (ca $6 \mathrm{~min}$ at reflux), the solution was cooled slightly and the volatiles were removed by rotary evaporation. After subsequent evacuation (ca 0.01 torr) for $15 \mathrm{~min}$, the resulting black residue was then diluted with $\mathrm{CHCl}_{3}(400 \mathrm{~mL})$ and remaining $\mathrm{POCl}_{3}$ was quenched by stirring with crushed ice for 15 min. The resulting layers were separated and the aqueous layer was extracted with additional $\mathrm{CHCl}_{3}(3 \times 50$ $\mathrm{mL})$. The organic layers were then combined, washed with saturated $\mathrm{NaHCO}_{3}(1 \times 150 \mathrm{~mL})$ and evaporated. The resulting deep red liquid was dissolved in 1:3 (v/v) EtOAc:hexanes and rapidly passed through a short column of $\mathrm{SiO}_{2}$ gel $(6 \times 7 \mathrm{~cm})$. The resulting deep red-orange oil $(5.89 \mathrm{~g}$; contaminated with $N, N$-dimethylaniline) was typically used in subsequent steps without further purification; however, a pure sample could be obtained by MPLC purification of ca $1 / 4$ of the crude sample (1.56 g) using a Biotage $25+\mathrm{M} \mathrm{SiO}_{2}$ gel column $(40 \mathrm{~g})$ eluing with EtOAc:hexanes $(1: 9 \rightarrow 1: 3,510 \mathrm{~mL}$ linear gradient) to yield 8 as a yellow-orange oil $(0.860 \mathrm{~g}, 45 \%)$. ${ }^{1} \mathrm{H}$ NMR $\left(400 \mathrm{MHz}, \mathrm{CDCl}_{3}, \delta\right): 1.47(\mathrm{t}, J=7.2 \mathrm{~Hz}, 3 \mathrm{H}), 4.55(\mathrm{q}, J=7.2$ $\mathrm{Hz}, 2 \mathrm{H}), 9.72(\mathrm{~s}, 1 \mathrm{H}) .{ }^{13} \mathrm{C} \mathrm{NMR}\left(100 \mathrm{MHz}, \mathrm{CDCl}_{3}, \delta\right): 14.1,63.8,148.5,153.9,155.2,161.3$. IR $(\mathrm{NaCl}$, neat) $\left(\mathrm{cm}^{-1}\right): 2984,2939,1743,1513$. UV (EtOH) $\lambda_{\max }(\log \varepsilon): 274(3.3), 388(1.9)$. HRMS-ESI $(\mathrm{m} / \mathrm{z})$ : $[\mathrm{M}+\mathrm{H}]^{+}$calcd for $\mathrm{C}_{6} \mathrm{H}_{7} \mathrm{~N}_{3} \mathrm{O}_{2} \mathrm{Cl}, 188.0227$; found, 188.0220 .

\section{$N$-(tert-Butoxycarbonyl)- $N$-methylhydrazine (9). ${ }^{5}$}

In a flame-dried, $250 \mathrm{~mL}$ round-bottom flask under an atmosphere of Ar, di-tert-butyl dicarbonate $(53.3 \mathrm{~g}, 245 \mathrm{mmol})$ was dissolved in anhydrous $\mathrm{CH}_{3} \mathrm{CN}(135 \mathrm{~mL})$ and the clear, colorless solution was cooled in an ice-water bath. Anhydrous methylhydrazine $(10.0 \mathrm{~mL}, 184 \mathrm{mmol})$ was then added dropwise over $10 \mathrm{~min}$ and the solution was allowed to warm to ambient temperature. After $24 \mathrm{~h}$, the solvent was removed by rotary evaporation and the crude product was fractionally distilled under vacuum $\left(30-35{ }^{\circ} \mathrm{C} @\right.$ ca 0.1 torr; lit. ${ }^{5} 65{ }^{\circ} \mathrm{C} @ 10$ torr) yielding 9 as a clear, colorless liquid $(17.3 \mathrm{~g}, 64 \%) .{ }^{1} \mathrm{H}$ NMR $(500 \mathrm{MHz}$, $\left.\mathrm{CDCl}_{3}, \delta\right): 1.47$ (s, 9H), $3.06(\mathrm{~s}, 3 \mathrm{H}), 4.09$ (bs, 2H).

\footnotetext{
${ }^{4}$ Attempts to crystallize 6 from mixtures of EtOAc:MeOH resulted in clear, colorless crystals. The crystals became opaque rapidly at $190-192{ }^{\circ} \mathrm{C}$ and melted sharply at $230-231{ }^{\circ} \mathrm{C}$.

${ }^{5}$ Procedure adapted from Metz, H. J.; Neunhoeffer, H. Chem. Ber. 1982, 115, 2807-2818.
} 


\section{Ethyl 6-(2-(tert-Butoxycarbonyl)-2-methylhydrazinyl)-1,2,4-triazine-5-carboxylate (10).}

In a $500 \mathrm{~mL}$ round-bottom flask under an atmosphere of Ar, crude chlorotriazine 8 (1.75 g, from $2.53 \mathrm{~g} \mathrm{7})$ was dissolved in absolute EtOH $(100 \mathrm{~mL})$. Hydrazide $9(2.76 \mathrm{~g}, 18.9 \mathrm{mmol})$ was added and the solution was heated to reflux. After $16 \mathrm{~h}$ at reflux, the reaction was cooled to ambient temperature and the solvent was removed by rotary evaporation. The crude residue was then dissolved in $\mathrm{CHCl}_{3}(100 \mathrm{~mL})$ and passed through a plug of $\mathrm{SiO}_{2}$ gel $(4 \times 8 \mathrm{~cm})$. The plug was washed with additional $\mathrm{CHCl}_{3}(500 \mathrm{~mL})$ and the combined filtrate and wash were evaporated to yield an orange oil $(2.6 \mathrm{~g})$. The crude product was purified by MPLC using a Biotage $40+\mathrm{M} \mathrm{SiO}_{2}$ gel column $(100 \mathrm{~g})$ eluted with EtOAc:hexanes $(1: 3 \rightarrow 1: 1$, $1320 \mathrm{~mL}$ linear gradient) to yield 10 as an orange oil $(1.92 \mathrm{~g}, 43 \%$ in 2 steps from 7$)$. ${ }^{1} \mathrm{H}$ NMR $(300 \mathrm{MHz}$, $\mathrm{CDCl}_{3}, \delta$ ): 1.37 (bs, 9H), 1.47 (t, $J=7.2 \mathrm{~Hz}, 3 \mathrm{H}$ ), 3.34 (s, 3H), 4.52 (q, $\left.J=7.2 \mathrm{~Hz}, 2 \mathrm{H}\right), 9.20$ (bs, $\left.1 \mathrm{H}\right), 9.40$ (s, 1H). ${ }^{13} \mathrm{C} \mathrm{NMR}\left(100 \mathrm{MHz}, \mathrm{CDCl}_{3}, \delta\right): 14.3,28.4,28.6,38.4,65.6,130.4,150.7,155.2,155.9,165.4$. IR $\left(\mathrm{NaCl}\right.$, neat) $\left(\mathrm{cm}^{-1}\right): 3351,2930,2930,1712,1556$. UV (EtOH) $\lambda_{\max }(\log \varepsilon): 241$ (3.9), 353 (3.3). HRMSESI (m/z): $[\mathrm{M}+\mathrm{H}]^{+}$calcd for $\mathrm{C}_{12} \mathrm{H}_{20} \mathrm{~N}_{5} \mathrm{O}_{4}, 298.1515$; found, 298.1511.

\section{1,2-Dihydro-2-methyl-3H-pyrazolo[4,3-e][1,2,4]triazin-3-one (11). ${ }^{6}$}

In a $250 \mathrm{~mL}$ round-bottom flask, $10(1.92 \mathrm{~g}, 6.46 \mathrm{mmol})$ was dissolved in a mixture of DCM (35 $\mathrm{mL})$ and trifluoroacetic acid $(35 \mathrm{~mL})$. After $40 \mathrm{~min}$ at ambient temperature, the solvent was evaporated to constant weight and the resulting TFA salt was dissolved in THF $(60 \mathrm{~mL})$. The solution was cooled in an ice-water bath and $\mathrm{NaH}$ (974 $\mathrm{mg}, 60 \%$ dispersion in oil, $24 \mathrm{mmol}$ ) was added in one portion. After the initial evolution of gas had subsided, the reaction was removed from the ice bath and stirred at ambient temperature. After $40 \mathrm{~min}$, the mixture was diluted with 1:1 (v/v) EtOAc:MeOH $(35 \mathrm{~mL})$ and passed through a plug of silica gel $(4 \times 8 \mathrm{~cm})$. The plug was washed with additional 1:1 (v/v) EtOAc:MeOH $(350$ $\mathrm{mL}$ ) and the filtrate was evaporated to yield a deep red solid. The crude material was then dissolved in $\mathrm{MeOH}(100 \mathrm{~mL})$, evaporated onto $\mathrm{SiO}_{2}(18.5 \mathrm{~g})$ and purified by chromatography using $\mathrm{SiO}_{2}(4 \mathrm{x} 18 \mathrm{~cm})$ eluting with a gradient from 1:3 $\rightarrow 1: 1$ EtOAc:MeOH to yield 11 as a red-purple solid $(0.850 \mathrm{~g}, 87 \%)$. Mp $145{ }^{\circ} \mathrm{C}$ dec. ${ }^{1} \mathrm{H}$ NMR $\left(300 \mathrm{MHz}, \mathrm{CD}_{3} \mathrm{OD}, \delta\right): 3.80(\mathrm{~s}, 3 \mathrm{H}), 9.11(\mathrm{~s}, 1 \mathrm{H}) .{ }^{13} \mathrm{C}$ NMR $\left(100 \mathrm{MHz}, \mathrm{CD}_{3} \mathrm{OD}, \delta\right)$ : 38.8, 126.5, 147.6, 154.1, 157.3. IR ( NaCl, thin film) $\left(\mathrm{cm}^{-1}\right): 3378,1605,1525$. UV (EtOH) $\lambda_{\max }(\log \varepsilon)$ : 259 (4.0), 2.95(sh) (3.4), 503 (2.9). HRMS-ESI (m/z): $[\mathrm{M}+\mathrm{H}]^{+}$calcd for $\mathrm{C}_{5} \mathrm{H}_{6} \mathrm{~N}_{5} \mathrm{O}, 152.0572$; found, 152.0565 .

\section{3-Methoxy-2-methyl-2H-pyrazolo[4,3-e][1,2,4]triazine (12).}

In a flame-dried, $100 \mathrm{~mL}$ round-bottom flask under an atmosphere of $\mathrm{Ar}, \mathbf{1 1}(0.0583 \mathrm{~g}, 0.384$ mmol) was dissolved in a 9:1 (v/v) mixture of acetonitrile:MeOH $(20 \mathrm{~mL})$. The deep red solution was cooled in an ice-water bath and $\mathrm{TMSCHN}_{2}(1.0 \mathrm{~mL}, 2.0 \mathrm{M}, 2.0 \mathrm{mmol})$ was added dropwise over $1 \mathrm{~min}$. After $45 \mathrm{~min}$, the mixture was poured directly onto a plug of silica gel $(2 \times 4 \mathrm{~cm})$. The plug was washed with 1:9 (v/v) MeOH:EtOAc $(35 \mathrm{~mL})$ and the eluate was evaporated to yield a mixture of dimethylated products as a green-purple oil $(0.0430 \mathrm{~g})$. The crude product was separated using a Biotage MPLC $12+\mathrm{M}$ $\mathrm{SiO}_{2}$ column $(8 \mathrm{~g})$ using EtOAc:hexanes $(1: 2 \rightarrow 1: 9,120 \mathrm{~mL}$ linear gradient) to yield yellow $12(0.0052 \mathrm{~g}$, $8 \%)$ as well as orange 1,2-dihydro-1,2-dimethyl-3H-pyrazolo[4,3-e][1,2,4]triazin-3-one (22; $0.0018 \mathrm{~g}, 3 \%)$ and purple 2,7-dihydro-2,7-dimethyl-3H-pyrazolo[4,3-e][1,2,4]triazin-3-one (23; $0.0098 \mathrm{~g}, 15 \%)^{7}$
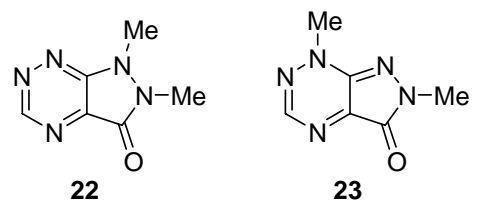

12: $\mathrm{Mp}^{8} 138-139^{\circ} \mathrm{C} .{ }^{1} \mathrm{H}$ NMR $\left(400 \mathrm{MHz}, \mathrm{CD}_{2} \mathrm{Cl}_{2}, \delta\right): 4.09$ (s, 3H), 4.60 (s, 3H), 9.50 (s, $\left.1 \mathrm{H}\right) .{ }^{13} \mathrm{C}$ NMR (100 MHz, $\left.\mathrm{CD}_{2} \mathrm{Cl}_{2}, \delta\right): 26.7,36.8,60.6,115.9,149.7,153.5$. IR ( $\mathrm{NaCl}$, thin film) $\left(\mathrm{cm}^{-1}\right)$ : 2921, 2851,

\footnotetext{
${ }^{6}$ The absence of a carbonyl peak in the IR suggests that this molecule exists as a tautomer.

${ }^{7}$ The structures of $\mathbf{2 2}$ and $\mathbf{2 3}$ were so assigned based on their synthesis from two different starting materials: 22 was isolated after the methylation of either $\mathbf{1 1}$ or $\mathbf{2 1}$ (see below); $\mathbf{2 3}$ was isolated after the methylation of either $\mathbf{2}$ (see below) or $\mathbf{1 1}$.
} 
1582. UV (EtOH) $\lambda_{\max }(\log \varepsilon): 234$ (4.1), 292 (3.7), 403 (3.2). HRMS-ESI (m/z): $[\mathrm{M}+\mathrm{H}]^{+}$calcd for $\mathrm{C}_{6} \mathrm{H}_{8} \mathrm{~N}_{5} \mathrm{O}, 166.0729$; found, 166.0736 .

22: $\mathrm{Mp}^{8} 157-159^{\circ} \mathrm{C} .{ }^{1} \mathrm{H}$ NMR $\left(400 \mathrm{MHz}, \mathrm{CD}_{2} \mathrm{Cl}_{2}, \delta\right): 3.58(\mathrm{~s}, 3 \mathrm{H}), 3.68(\mathrm{~s}, 3 \mathrm{H}), 9.72(\mathrm{~s}, 1 \mathrm{H}) \cdot{ }^{13} \mathrm{C} \mathrm{NMR}$ $\left(100 \mathrm{MHz}, \mathrm{CD}_{2} \mathrm{Cl}_{2}, \delta\right): 29.7,35.0,134.8,154.1,155.6,157.5$. IR $\left(\mathrm{NaCl}\right.$, thin film) $\left(\mathrm{cm}^{-1}\right): 2925,1697$, 1573. UV (EtOH) $\lambda_{\max }(\log \varepsilon): 254(4.1), 391$ (3.3). HRMS-ESI $(\mathrm{m} / \mathrm{z}):[\mathrm{M}+\mathrm{H}]^{+}$calcd for $\mathrm{C}_{6} \mathrm{H}_{8} \mathrm{~N}_{5} \mathrm{O}$, 166.0729; found, 166.0726 .

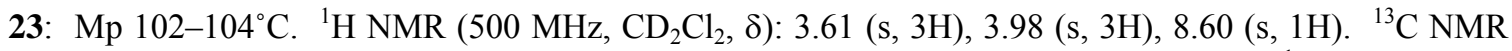
$\left(125 \mathrm{MHz}, \mathrm{CD}_{2} \mathrm{Cl}_{2}, \delta\right): 33.4,41.2,135.6,141.7,154.4,156.8$. IR $\left(\mathrm{NaCl}\right.$, thin film) $\left(\mathrm{cm}^{-1}\right): 2927,1684$, 1625, 1577. UV (EtOH) $\lambda_{\max }(\log \varepsilon): 245$ (3.8), 298(sh) (3.4), 552 (2.9). HRMS-ESI $(\mathrm{m} / \mathrm{z}):[\mathrm{M}+\mathrm{H}]^{+}$ calcd for $\mathrm{C}_{6} \mathrm{H}_{8} \mathrm{~N}_{5} \mathrm{O}, 166.0729$; found, 166.0732 .

\section{Ethyl 6-(2-(tert-Butoxycarbonyl)hydrazinyl)-1,2,4-triazine-5-carboxylate (14).}

In a $1 \mathrm{~L}$ round-bottom flask under an atmosphere of $\mathrm{Ar}$, crude chlorotriazine $8(11.5 \mathrm{~g}$, from $14.5 \mathrm{~g}$ 7) was dissolved in absolute EtOH $(400 \mathrm{~mL}) . N$-(tert-Butoxycarbonyl)hydrazine ${ }^{9}(16.0 \mathrm{~g}, 121 \mathrm{mmol})$ was added and the solution was heated at reflux. After $2 \mathrm{~h}$, the reaction was cooled to ambient temperature and the solvent was evaporated. The residue was partitioned between DCM $(150 \mathrm{~mL})$ and saturated $\mathrm{NaHCO}_{3}$ $(150 \mathrm{~mL})$. The organic layer was then washed with saturated $\mathrm{NaHCO}_{3}(75 \mathrm{~mL})$. The aqueous layer $(\mathrm{pH}=$ 7) was basified to $\mathrm{pH}=12$ with $5 \mathrm{M}$ aqueous $\mathrm{NaOH}$ (ca $10 \mathrm{~mL}$ ). The now-basic layer was extracted with $\operatorname{DCM}(2 \times 75 \mathrm{~mL})$ and the organic extracts were combined, dried over $\mathrm{MgSO}_{4}$ and evaporated. The residue chromatographed using $\mathrm{SiO}_{2}(6 \times 20 \mathrm{~cm})$ eluting with DCM followed by 1:9 (v/v) EtOAc:DCM to yield 14 as an orange, extremely viscous oil ( $11.5 \mathrm{~g}, 47 \%$ in 2 steps from 7). ${ }^{1} \mathrm{H} \mathrm{NMR}\left(300 \mathrm{MHz}, \mathrm{CDCl}_{3}, \delta\right): 1.47$ (t, $J=7.2 \mathrm{~Hz}, 3 \mathrm{H}), 1.49$ (bs, 9H), 4.52 (q, $J=7.2 \mathrm{~Hz}, 2 \mathrm{H}), 6.78$ (bs, $1 \mathrm{H}), 9.05$ (d, $J=3 \mathrm{~Hz}, 1 \mathrm{H}), 9.39$ (s, 1H). $\left.{ }^{13} \mathrm{C} \mathrm{NMR} \mathrm{(100} \mathrm{MHz,} \mathrm{CDCl}_{3}, \delta\right): 14.4,28.4,28.5,63.7,130.6,150.7,155.4,156.0,165.3$. IR $(\mathrm{NaCl}$, neat) $\left(\mathrm{cm}^{-1}\right): 3349,3284,2980,2936,1712,1562,1511$. UV (EtOH) $\lambda_{\max }(\log \varepsilon): 236$ (3.9), 356 (3.4). HRMS-ESI (m/z): $[\mathrm{M}+\mathrm{H}]^{+}$calcd for $\mathrm{C}_{11} \mathrm{H}_{18} \mathrm{~N}_{5} \mathrm{O}_{4}, 284.1359$; found, 284.1353 .

\section{1,2-Dihydro-3H-pyrazolo[4,3-e][1,2,4]triazin-3-one (15). ${ }^{6}$}

In a $500 \mathrm{~mL}$ round-bottom flask under an atmosphere of $\operatorname{Ar}, 14(11.5 \mathrm{~g}, 40.6 \mathrm{mmol})$ was dissolved in DCM $(300 \mathrm{~mL})$. Thioanisole $(6.5 \mathrm{~mL}, 55 \mathrm{mmol})$ was added followed by addition of trifluoroacetic acid $(75 \mathrm{~mL})$. The reaction was stirred for $5 \mathrm{~h}$ at ambient temperature and then evaporated to a constant weight. The residue was dissolved in $\mathrm{MeOH}(300 \mathrm{~mL})$ and carefully neutralized with the aid of a pH meter ${ }^{10}$ to $\mathrm{pH}$ $=7.4$ using crushed potassium hydroxide. After stirring for $2.5 \mathrm{~h}$, silica $(15 \mathrm{~g})$ was added to the deep red solution and the solvent was removed. Chromatography using $\mathrm{SiO}_{2}(4 \times 10 \mathrm{~cm})$ eluting with a solvent gradient $(400 \mathrm{~mL}$ 1:1 EtOAc:hexanes; $400 \mathrm{~mL}$ EtOAc; $500 \mathrm{~mL}$ 1:9 MeOH:EtOAc; 1.5 L 2:1:1 $\mathrm{MeOH}$ :EtOAc:hexanes) yielded $\mathbf{1 5}$ as a bright red-orange solid $(1.95 \mathrm{~g}, 35 \%)$. Triazinone 15 was conveniently manipulated as its $\mathrm{HCl}$ salt, which could be obtained by acidification of a methanolic solution of 15 with excess conc. $\mathrm{HCl}(\mathrm{aq})$, followed by evaporation to yield the bright yellow $15 \cdot \mathrm{HCl}(=\mathbf{1 5 a})$.

15: $\mathrm{Mp} 140{ }^{\circ} \mathrm{C}$ dec. ${ }^{1} \mathrm{H} \mathrm{NMR}^{11}\left(400 \mathrm{MHz}, \mathrm{CD}_{3} \mathrm{OD}, \delta\right): 9.45$ (s, $\left.1 \mathrm{H}\right) .{ }^{13} \mathrm{C} \mathrm{NMR}\left(100 \mathrm{MHz}, \mathrm{CD}_{3} \mathrm{OD}, \delta\right)$ : 127.4, 150.5, 151.5, 157.2. IR (NaCl, think film) $\left(\mathrm{cm}^{-1}\right): 3485,3365,2922,1643,1510$. UV (EtOH) $\lambda_{\max }$ (log $\varepsilon): 238$ (3.7), 252sh (3.6), 282sh (3.3), 377 (2.6), 499 (2.5). HRMS-ESI (m/z): $[\mathrm{M}+\mathrm{H}]^{+}$calcd for $\mathrm{C}_{4} \mathrm{H}_{4} \mathrm{~N}_{5} \mathrm{O}, 138.0416$; found, 138.0418 .

\section{Nostocine A (2) and Fluviol A (3).}

In a flame-dried, $250 \mathrm{~mL}$ round-bottom flask under an atmosphere of $\mathrm{Ar}, \mathbf{1 5} \bullet \mathrm{HCl}(0.337 \mathrm{~g}, 1.95$ mmol) was dissolved in a 1:4 (v/v) mixture of $\mathrm{MeOH}: \mathrm{CH}_{3} \mathrm{CN}(50 \mathrm{~mL})$. TMSCHN $2(0.50 \mathrm{~mL}, 2.0 \mathrm{M}, 1.0$ $\mathrm{mmol}$ ) was added in one portion and the reaction was stirred at ambient temperature for $30 \mathrm{~min}$. The

\footnotetext{
${ }^{8}$ Needles from DCM/hexanes.

${ }^{9}$ Commercially available from Aldrich: tert-Butyl carbazate.

${ }^{10} \mathrm{~A} 0.25 \mathrm{~mL}$ aliquot was removed from the reaction and was diluted with water $(1 \mathrm{~mL})$ prior to $\mathrm{pH}$ analysis.

${ }^{11}$ 15• HCl: ${ }^{1} \mathrm{H}$ NMR (400 MHz, $\left.\mathrm{CD}_{3} \mathrm{OD}, \delta\right): 9.75$ (s, $\left.1 \mathrm{H}\right) ; \mathbf{1 5}^{-} \mathrm{K}^{+}:{ }^{1} \mathrm{H}$ NMR (400 MHz, $\left.\mathrm{CD}_{3} \mathrm{OD}, \delta\right): 8.97$.
} 
solvent was then removed and $\mathrm{CHCl}_{3}(100 \mathrm{~mL})$ was added to the resulting residue. After sonication for 20 min, the suspension was filtered and the filter cake (which we believe is a mixture of $\mathbf{1 5}$ and $\mathbf{1 5} \cdot \mathrm{HCl}$ ) was washed with additional $\mathrm{CHCl}_{3}(50 \mathrm{~mL})$ until the filtrate ran colorless. The yellow-red filter cake was evacuated to dryness $(0.178 \mathrm{~g})$ and dissolved in 1:4 (v/v) $\mathrm{MeOH}: \mathrm{CH}_{3} \mathrm{CN}(25 \mathrm{~mL})$ under an atmosphere of Ar. $\mathrm{TMSCHN}_{2}(0.30 \mathrm{~mL}, 2.0 \mathrm{M}, 0.60 \mathrm{mmol})$ was added in one portion and the reaction was stirred at ambient temperature for $30 \mathrm{~min}$. The solvent was then removed and $\mathrm{CHCl}_{3}(25 \mathrm{~mL})$ was added to the resulting residue. After sonication for $20 \mathrm{~min}$, the suspension was allowed to settle and the supernatant was carefully removed by pipet. The procedure was repeated until the extract was colorless. The red residue was evacuated to dryness $(0.105 \mathrm{~g})$ and dissolved in 1:4 (v/v) $\mathrm{MeOH}: \mathrm{CH}_{3} \mathrm{CN}(15 \mathrm{~mL})$ under an atmosphere of Ar. $\mathrm{TMSCHN}_{2}(0.15 \mathrm{~mL}, 2.0 \mathrm{M}, 0.30 \mathrm{mmol})$ was added in one portion and the reaction was stirred at ambient temperature for $30 \mathrm{~min}$. The solvent was then removed and the solid was extracted with $\mathrm{CHCl}_{3}$ as above. The filtrates and extracts from the three cycles were combined and evaporated yielding a purplebrown solid $(0.300 \mathrm{~g})$ consisting of multiple mono- and dimethylated products. The crude material was dissolved in $\mathrm{MeOH}(10 \mathrm{~mL})$ and evaporated onto $\mathrm{SiO}_{2}$ gel $(1.5 \mathrm{~g}) . \mathrm{SiO}_{2}$ gel chromatography $(4 \mathrm{x} 8 \mathrm{~cm})$ eluting first with 1:1 (v/v) EtOAc:hexanes $(500 \mathrm{~mL})$ then 1:19 (v/v) MeOH:EtOAc $(500 \mathrm{~mL})$ yielded two major fractions; one yellow and one purple. The yellow fraction was further purified by MPLC using a Biotage $12+\mathrm{M} \mathrm{SiO}_{2}$ column $(8 \mathrm{~g})$ eluting with EtOAc:hexanes $(1: 9 \rightarrow 1: 5,120 \mathrm{~mL}$ linear gradient; $1: 5 \rightarrow 1: 1$, $120 \mathrm{~mL}$ linear gradient; $1: 1120 \mathrm{~mL}$ isocratic) to yield fluviol A (3) as a bright yellow solid $(0.054 \mathrm{~g}, 18 \%)$. The purple fraction was further purified by MPLC using a Biotage $12+\mathrm{M} \mathrm{SiO}_{2}$ column (8 g) eluting with $\mathrm{MeOH}:$ EtOAc $(1: 99 \rightarrow 1: 19,240 \mathrm{~mL}$ linear gradient; 1:19, $120 \mathrm{~mL}$ isocratic) to yield nostocine $\mathrm{A}(2)$ as a deep purple solid $(0.013 \mathrm{~g}, 4 \%)$.

Nostocine A (2): $\mathrm{Mp}^{12} 168-170{ }^{\circ} \mathrm{C}$ (lit. $\left.{ }^{13} 171-172{ }^{\circ} \mathrm{C}\right) .{ }^{1} \mathrm{H}$ NMR $\left(400 \mathrm{MHz}, \mathrm{CD}_{3} \mathrm{OD}, \delta\right): 4.04$ (s, 3H), $8.76(\mathrm{~s}, 1 \mathrm{H}) .{ }^{1} \mathrm{H}$ NMR $\left(400 \mathrm{MHz}, \mathrm{CDCl}_{3}, \delta\right): 4.03(\mathrm{~s}, 3 \mathrm{H}), 8.66(\mathrm{~s}, 1 \mathrm{H}) .{ }^{13} \mathrm{C}$ NMR $\left(125 \mathrm{MHz}, \mathrm{CD}_{3} \mathrm{OD}, \delta\right)$ : 41.5, 138.6, 142.7, 154.6, 161.1. IR ( NaCl, thin film) $\left(\mathrm{cm}^{-1}\right): 3300,2964,2930,1677,1622,1577$. UV $(\mathrm{MeOH}) \lambda_{\max }(\log \varepsilon): 240$ (3.8), 290(sh) (3.4), 548(br) (3.0). UV (EtOH) $\lambda_{\max }(\log \varepsilon): 240$ (3.8), 283sh (3.4), 541 (br) (3.0). HRMS-ESI (m/z): $[\mathrm{M}+\mathrm{H}]^{+}$calcd for $\mathrm{C}_{5} \mathrm{H}_{6} \mathrm{~N}_{5} \mathrm{O}, 152.0572$; found, 152.0570 .

Fluviol A (3): Mp 198-201 ${ }^{\circ} \mathrm{C}$ (lit. ${ }^{14 a}$ fluviol A: $196-197{ }^{\circ} \mathrm{C}$; lit. ${ }^{14 b}$ normethylpseudoiodinine: $196{ }^{\circ} \mathrm{C}$ ). ${ }^{1} \mathrm{H}$ NMR (400 MHz, $\left.\mathrm{CDCl}_{3}, \delta\right): 4.24$ (s, 3H), 9.77 (s, 1H), 10.2 (bs, 1H). ${ }^{1} \mathrm{H}$ NMR (400 MHz, $\left.\mathrm{CD}_{3} \mathrm{OD}, \delta\right)$ : $4.20(\mathrm{~s}, 3 \mathrm{H}), 9.64(\mathrm{~s}, 1 \mathrm{H}) .{ }^{13} \mathrm{C} \mathrm{NMR}\left(125 \mathrm{MHz}, \mathrm{CDCl}_{3}, \delta\right): 57.1,126.0,149.9,152.1,155.5$. IR $(\mathrm{NaCl}$, thin film) $\left(\mathrm{cm}^{-1}\right): 3134,2978,2908,1586,1558$. UV (EtOH) $\lambda_{\max }(\log \varepsilon): 228$ (3.9), 283 (3.5), 372 (3.1). $\mathrm{UV}\left(\mathrm{CH}_{2} \mathrm{Cl}_{2}\right) \lambda_{\max }$ (log $\varepsilon$ ): 223 (4.0), 278 (3.5), 282(3.5), 289sh (3.4), 362 (br) (3.2). HRMS-ESI (m/z): $[\mathrm{M}+\mathrm{H}]^{+}$calcd for $\mathrm{C}_{5} \mathrm{H}_{6} \mathrm{~N}_{5} \mathrm{O}, 152.0572$; found, 152.0581 .

\section{Methylation of Fluviol A (3) to Give Pseudoiodinine Following the Procedure of Lindner and Schaden. ${ }^{15}$}

In a $250 \mathrm{~mL}$ Erlenmeyer flask, fluviol A (3) $(0.0750 \mathrm{~g}, 0.496 \mathrm{mmol})$ was stirred as a mostly dissolved suspension in $\mathrm{Et}_{2} \mathrm{O}(10 \mathrm{~mL})$. Freshly prepared diazomethane ${ }^{16}(40 \mathrm{~mL}, \sim 0.8 \mathrm{M}, \sim 32 \mathrm{mmol})$ was added in one portion and the reaction was stirred for $2 \mathrm{~h}$. Subsequent evaporation, followed by MPLC purification using a Biotage $25+\mathrm{M} \mathrm{SiO}_{2}$ column $(40 \mathrm{~g})$ eluted with acetone:DCM $(1: 2,510 \mathrm{~mL}$ isocratic; $1: 1,1020 \mathrm{~mL}$ isocratic) yielded a yellow-orange solid $(20,0.021 \mathrm{~g}, 25 \%),{ }^{17}$ and a purple solid ${ }^{18}(0.0060 \mathrm{~g}$,

\footnotetext{
12 Small prisms from EtOAc.

${ }^{13}$ Hirate, K.; Nakagami, H.; Takashina, J.; Mahmud, T.; Kobayashi, M.; In, Y.; Ishida, T.; Miyamoto, K. Heterocycles 1996, 43, 1513-1519. Spectral data reported for Nostocine A: ${ }^{1} \mathrm{H}$ NMR $\left(270 \mathrm{MHz}, \mathrm{CD}_{3} \mathrm{OD}, \delta\right): 4.02(\mathrm{~s}, 3 \mathrm{H}), 8.74(\mathrm{~s}, 1 \mathrm{H}) .{ }^{13} \mathrm{C}$ NMR $(100$ $\left.\mathrm{MHz}, \mathrm{CD}_{3} \mathrm{OD}, \delta\right): 42.3,139.4,143.5,155.4,161.8$. IR $(\mathrm{KBr})\left(\mathrm{cm}^{-1}\right): 3482,2463,1676,1627 . \mathrm{UV}(\mathrm{MeOH}) \lambda_{\max }(\log \varepsilon): 239(3.8)$, 277(sh) (3.5), $555(3.0)$.

14 a) Smirnov, V. V.; Kiprianova, E. A.; Garagulya, A. D.; Esipov, S. E.; Dovjenko, S. A. FEMS Microbiol. Let.. 1997, 153, 357361 and personal communication from Dovjenko, S. A. Spectral data reported for fluviol A: ${ }^{1} \mathrm{H}$ NMR $\left(\mathrm{CDCl}_{3}, \delta\right): 4.25(\mathrm{~s}, 3 \mathrm{H}), 9.78$ (s, 1H), 10.24 (s, 1H); ${ }^{1} \mathrm{H}$ NMR (DMSO-d6, $\left.\delta\right): 4.15$ (s, 3H), 9.76 (s, 1H), 12.09 (s, 1H); ${ }^{1} \mathrm{H}$ NMR (acetone-d6, $\delta$ ): 4.20 (s, 3H), 9.71 (s, 1H), $12.80(\mathrm{~s}, 1 \mathrm{H})$. UV (EtOH) $\lambda_{\max }(\log \varepsilon): 233(4.16), 280(3.56), 283$ (3.56), 375 (3.16). b) (ref. 15). Spectral data reported for normethylpseudoiodinine: $\mathrm{IR}(\mathrm{KBr})\left(\mathrm{cm}^{-1}\right): 3100$. UV $\left(\mathrm{CH}_{2} \mathrm{Cl}_{2}\right) \lambda_{\max }: 231,277,281,287,360,402$.

${ }^{15}$ Lindner, H. J.; Schaden, G. Chem. Ber. 1972, 105, 1949-1955.

${ }^{16}$ Prepared according to the procedure outlined in note 3 of Arndt, F. Org. Synth. 1943, Coll. Vol. 2, 165-167.

${ }^{17}$ This is the so-called hauptprodukt of Lindner and Schaden ${ }^{15}$, whose structure assignment was confirmed by methylation of 21
} 
$7 \%$ ) identical to pseudoiodinine. Crystallization of pseudoiodinine was accomplished by dissolving 0.0050 $\mathrm{g}$ in acetone $(0.080 \mathrm{~mL})$ and carefully layering hexanes $(0.160 \mathrm{~mL})$ on top. Deep black-purple crystals $(0.003 \mathrm{~g})$ slowly formed upon sitting at ambient temperature overnight.

20: $\mathrm{Mp}^{8} 154-155{ }^{\circ} \mathrm{C}\left(\right.$ lit. $\left.^{17} 149{ }^{\circ} \mathrm{C}\right) .{ }^{1} \mathrm{H}$ NMR $\left(400 \mathrm{MHz}, \mathrm{CDCl}_{3}, \delta\right.$ ): 4.19 (s, 3H), 4.21 (s, 3H), 9.69 (s, 1H). ${ }^{1} \mathrm{H}$ NMR $\left(400 \mathrm{MHz}, \mathrm{CD}_{2} \mathrm{Cl}_{2}, \delta\right): 4.15(\mathrm{~s}, 3 \mathrm{H}), 4.18(\mathrm{~s}, 3 \mathrm{H}), 9.62(\mathrm{~s}, 1 \mathrm{H}) .{ }^{13} \mathrm{C} \mathrm{NMR}(100 \mathrm{MHz}$, $\left.\mathrm{CD}_{2} \mathrm{Cl}_{2}, \delta\right): 34.6,57.5,125.4,148.8,151.5,154.0$. IR (NaCl, thin film) $\left(\mathrm{cm}^{-1}\right): 3067,2982,1574,1552$. UV $\left(\mathrm{CH}_{2} \mathrm{Cl}_{2}\right) \lambda_{\max }(\log \varepsilon): 237$ (4.0), 280 (3.5), 285(3.5), 295sh (3.4), 397 (br) (3.1). UV (EtOH) $\lambda_{\max }(\log$ ع): 237 (4.1), 284 (3.5), 388 (3.2). HRMS-ESI (m/z): $[\mathrm{M}+\mathrm{H}]^{+}$calcd for $\mathrm{C}_{6} \mathrm{H}_{8} \mathrm{~N}_{5} \mathrm{O}, 166.0729$; found, 166.0732 .

Pseudoiodinine: $\mathrm{Mp} 120-123{ }^{\circ} \mathrm{C}\left(\right.$ lit. $\left.{ }^{15} 112{ }^{\circ} \mathrm{C}\right) .{ }^{1} \mathrm{H} \mathrm{NMR}^{19}\left(500 \mathrm{MHz}, \mathrm{CD}_{2} \mathrm{Cl}_{2}, \delta\right): 4.27(\mathrm{~s}, 3 \mathrm{H}), 4.41$ (s, $3 \mathrm{H}), 8.95(\mathrm{~s}, 1 \mathrm{H}) .{ }^{13} \mathrm{C} \mathrm{NMR}\left(125 \mathrm{MHz}, \mathrm{CD}_{2} \mathrm{Cl}_{2}, \delta\right): 43.0,57.6,139.0,142.6,146.0,160.7$. IR ( NaCl, thin film) $\left(\mathrm{cm}^{-1}\right): 2988,2924,2851,1586,1537 . \mathrm{UV}\left(\mathrm{CH}_{2} \mathrm{Cl}_{2}\right) \lambda_{\max }(\log \varepsilon): 230$ (3.6), 255 (3.5), 295 (3.2), 533 (2.6). UV (EtOH) $\lambda_{\max }(\log \varepsilon): 220$ (3.7), 254 (3.6), 295sh (3.4), 520 (2.6). HRMS-ESI (m/z): $[\mathrm{M}+\mathrm{H}]^{+}$ calcd for $\mathrm{C}_{6} \mathrm{H}_{8} \mathrm{~N}_{5} \mathrm{O}, 166.0729$; found, 166.0737 .

\section{1,2-Dihydro-1-methyl-3H-pyrazolo[4,3-e][1,2,4]triazin-3-one (21). ${ }^{6}$}

In a $250 \mathrm{~mL}$ round-bottom flask under an atmosphere of $\mathrm{Ar}$, crude chlorotriazine $8(1.678 \mathrm{~g})$ was dissolved in absolute EtOH $(100 \mathrm{~mL})$. Methylhydrazine $(0.50 \mathrm{~mL}, 9.3 \mathrm{mmol})$ was added dropwise over 1.5 min and the solution was stirred at ambient temperature overnight. The resulting yellow solution was evaporated to yield a red-orange solid. The crude product was purified by chromatography using $\mathrm{SiO}_{2}(4 \mathrm{x}$ $10 \mathrm{~cm}$ ) eluting first with 1:2 (v/v) EtOAc:hexanes $(300 \mathrm{~mL})$, followed by 1:9 (v/v) MeOH:EtOAc $(500 \mathrm{~mL})$ to yield 21 as a yellow-orange solid $(0.634 \mathrm{~g}, 27 \%$ in 2 steps from 7$) . \mathrm{Mp}^{8} 199-200{ }^{\circ} \mathrm{C}$. ${ }^{1} \mathrm{H}$ NMR (400 $\left.\mathrm{MHz}, \mathrm{CD}_{3} \mathrm{OD}, \delta\right): 4.09$ (s, 3H), $9.61(\mathrm{~s}, 1 \mathrm{H}) .{ }^{1} \mathrm{H}$ NMR $\left(400 \mathrm{MHz}, \mathrm{CDCl}_{3}, \delta\right): 4.18(\mathrm{~s}, 3 \mathrm{H}), 9.66(\mathrm{~s}, 1 \mathrm{H})$. ${ }^{13} \mathrm{C}$ NMR $\left(125 \mathrm{MHz}, \mathrm{CD}_{3} \mathrm{OD}, \delta\right): 34.3,127.0,149.0,151.6,153.9$. IR $\left(\mathrm{NaCl}\right.$, thin film) $\left(\mathrm{cm}^{-1}\right): 2997$, 2924, 2848, 1574. UV (EtOH) $\lambda_{\max }(\log \varepsilon): 237$ (4.0), 283 (3.5), 405 (3.7). HRMS-ESI (m/z): $[\mathrm{M}+\mathrm{H}]^{+}$ calcd for $\mathrm{C}_{5} \mathrm{H}_{6} \mathrm{~N}_{5} \mathrm{O}, 152.0572$; found, 152.0568 .

\section{3-Methoxy-1-methyl-1H-pyrazolo[4,3-e][1,2,4]triazine (20).}

In a flame-dried, $50 \mathrm{~mL}$ round-bottom flask under an atmosphere of Ar, $21(0.0340 \mathrm{~g}, 0.225$ mmol) was dissolved in a 9:1 (v/v) mixture of $\mathrm{CH}_{3} \mathrm{CN}: \mathrm{MeOH}(10 \mathrm{~mL})$. The yellow solution was cooled in an ice-water bath and $\mathrm{TMSCHN}_{2}(0.550 \mathrm{~mL}, 2.0 \mathrm{M}, 1.1 \mathrm{mmol})$ was added dropwise over $1.5 \mathrm{~min}$. After 20 min, the mixture was poured directly onto a plug of $\mathrm{SiO}_{2}$ gel $(2 \times 4 \mathrm{~cm})$. The plug was washed with 1:1 $(\mathrm{v} / \mathrm{v}) \mathrm{MeOH}$ :EtOAc $(25 \mathrm{~mL})$ and the eluate was evaporated to yield a yellow-orange solid. The crude product was purified by MPLC using a Biotage $12+\mathrm{M} \mathrm{Si}_{2} \mathrm{O}$ column $(8 \mathrm{~g})$ eluting with EtOAc:hexanes $(1: 2 \rightarrow$ EtOAc, $240 \mathrm{~mL}$ linear gradient) to give a yellow solid $(0.0223 \mathrm{~g}, 60 \%)$ identical to 20 , as well as an orange solid $(0.0040 \mathrm{~g}, 10 \%)$ identical to 22 .

\section{Methylation of Nostocine A (2) to Give Pseudoiodinine.}

In a $50 \mathrm{~mL}$ Erlenmeyer flask, nostocine A (2) $(0.0040 \mathrm{~g}, 0.026 \mathrm{mmol})$ was dissolved in $\mathrm{Et}_{2} \mathrm{O}(3$ $\mathrm{mL})$. Freshly distilled diazomethane $\mathrm{e}^{20}(0.75 \mathrm{~mL}, \sim 0.08 \mathrm{M}, \sim 0.05 \mathrm{mmol})$ was added and the reaction was stirred for $1 \mathrm{~h}$. Subsequent evaporation, followed by MPLC purification using a Biotage $12+\mathrm{M} \mathrm{SiO}_{2}$ column (8 g) eluting with MeOH:EtOAc $(1: 99,120 \mathrm{~mL}$ isocratic; 1:99 $\rightarrow 1: 19,240 \mathrm{~mL}$ linear gradient;

(see below); Spectral data reported for the hauptprodukt: ${ }^{1} \mathrm{H}$ NMR (60 MHz, $\left.\mathrm{CDCl}_{3}, \delta\right): 4.22$ (s, 3H), 4.26 (s, 3H), 9.72 (s, 1H). UV $\left(\mathrm{CH}_{2} \mathrm{Cl}_{2}\right) \lambda_{\text {max }}: 234,275,280,285,291,386,410$.

${ }^{18}$ The material is red as a TLC spot and in dilute solution.

${ }^{19}$ Ref. 15 reports the ${ }^{1} \mathrm{H}$ NMR spectrum $\left(\mathrm{CH}_{2} \mathrm{Cl}_{2}\right)$ of pseudoiodinine as $\delta 4.38(\mathrm{~s}, 3 \mathrm{H}), 4.58(\mathrm{~s}, 3 \mathrm{H}), 9.26(\mathrm{~s}, 1 \mathrm{H})$. We believe the discrepancy between our chemical shifts and those of ref. 15 are due to an incorrectly calibrated permanent magnet in the original (ca 1972) work (the magnitude of the discrepancy is roughly proportional to the chemical shift). The UV/vis spectra and mps are in good agreement and the methods of preparation are identical. Other spectral data reported for pseudoiodinine: $\mathrm{UV}\left(\mathrm{CH}_{2} \mathrm{Cl}_{2}\right): 254,295$, $374,536$.

20 a) de Boer, J.; Backer, H. J. Org. Synth. 1963, Coll. Vol. 4, 250-253. b) Titrated as described in ref. 16. 
$1: 19,120 \mathrm{~mL}$ isocratic) yielded a purple solid $(0.0014 \mathrm{~g}, 33 \%)$ identical to 23 and a red-purple solid $(0.0004 \mathrm{~g}, 9 \%)$ identical to $19 .{ }^{21}$

\footnotetext{
${ }^{21}$ Fluviol $\mathrm{C}^{14 a}$ has been assigned structure 19, but unlike synthetic 19 which is red (purple as a solid), fluviol $\mathrm{C}$ is reported to be yellow and its reported UV/vis spectrum and melting point are at variance with those found for synthetic 19. Consequently, we conclude that the structure assigned to fluviol $\mathrm{C}$ is incorrect.

Based on its propensity to suffer demethylation to 3, its reported violet color $\left(19\right.$ is purple as a solid), its $\mathrm{mp}\left(128^{\circ} \mathrm{C}\right.$, dec; 120 $123{ }^{\circ} \mathrm{C}$ for 19) and its UV/vis spectrum $\{\mathrm{UV}(\mathrm{EtOH})(\log \varepsilon): 221$ (4.08), 253 (3.94), $296(3.59), 520(3.06)\}$, we suspect fluviol $\mathrm{E}^{14 \mathrm{a}}$ is identical to pseudoiodinine (19) and that the structure (18) assigned to fluviol E is incorrect. Unfortunately, the ${ }^{1} \mathrm{H}$ NMR spectra of fluviols B-E have not been reported, so the identity of fluviol E with pseudoiodinine cannot be proposed with complete certainty.
} 


\section{Selected Spectra}

Ethyl 1,4,5,6-Tetrahydro-6-oxo-1,2,4-triazine-5-carboxylate (6).
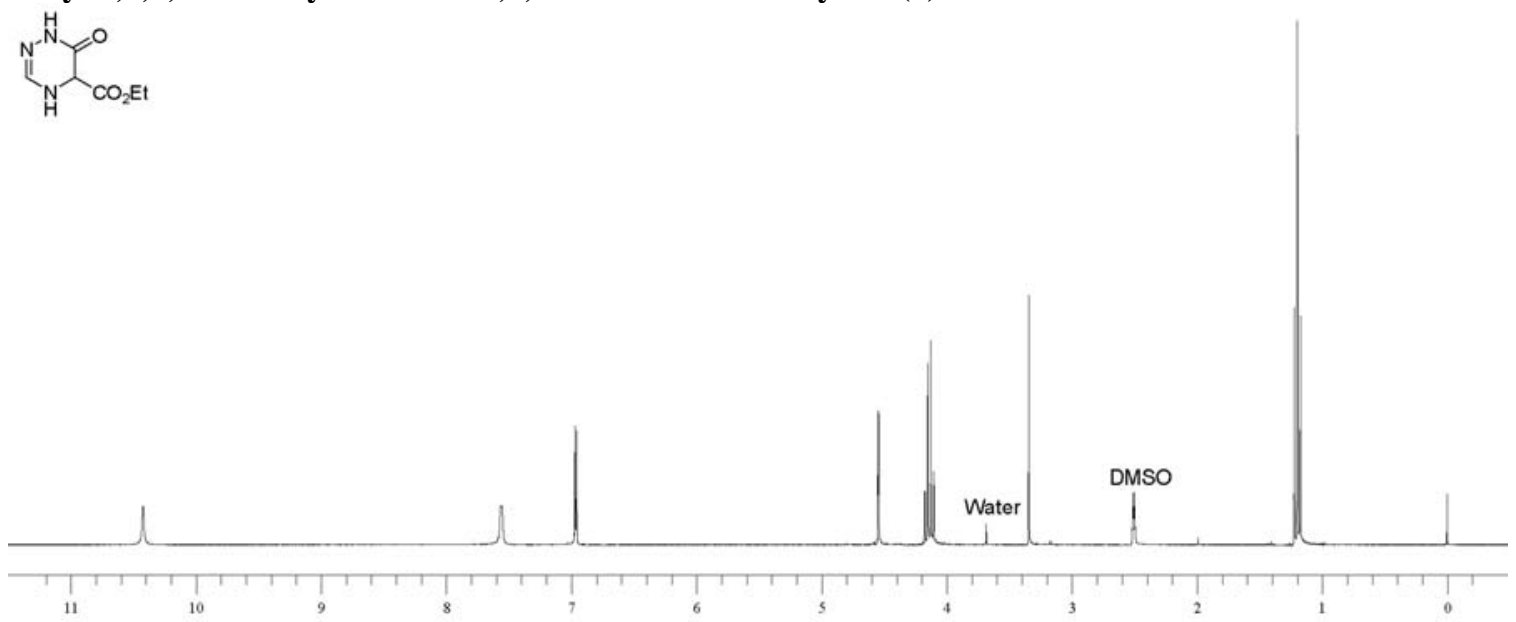

Ethyl 1,6-Dihydro-6-oxo-1,2,4-triazine-5-carboxylate (7).
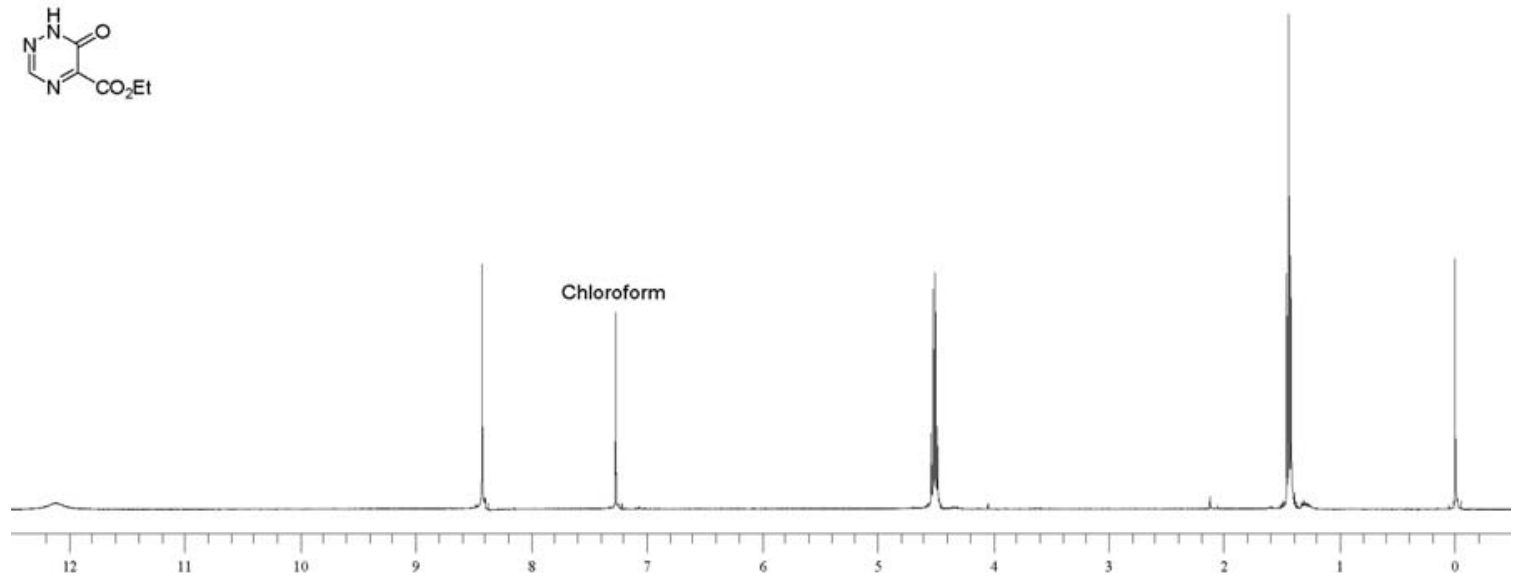
Ethyl 6-Chloro-1,2,4-triazine-5-carboxylate (8).
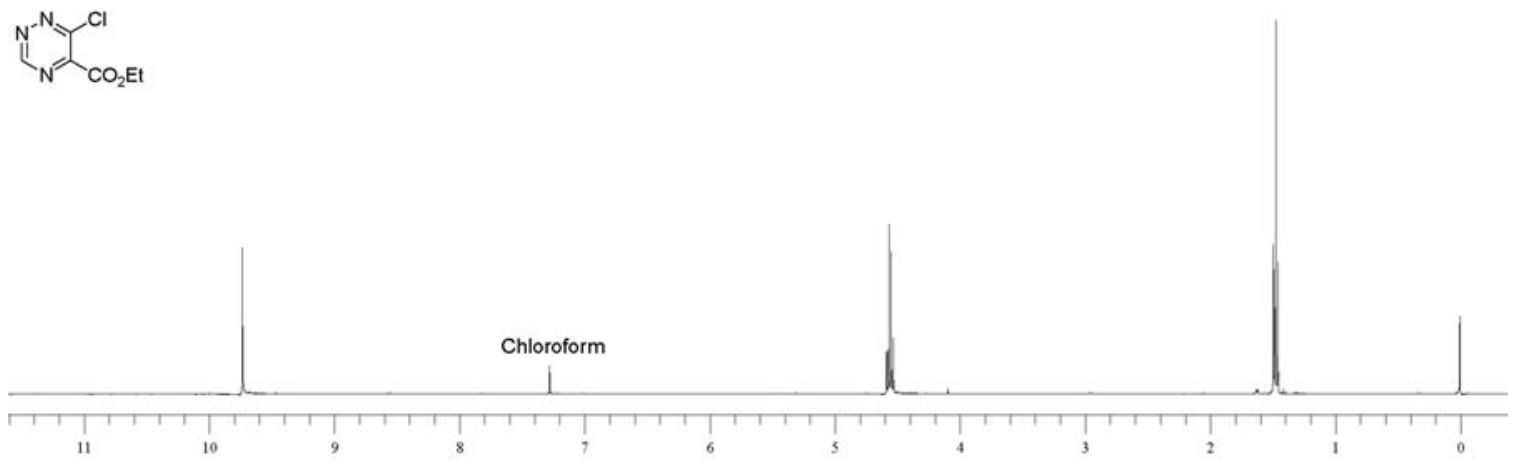

$N$-(tert-Butoxycarbonyl)- $N$-methylhydrazine (9).

$\mathrm{H}_{2} \mathrm{~N}^{-\stackrel{\mathrm{B}}{\mathrm{N}_{-}} \mathrm{Mec}}$
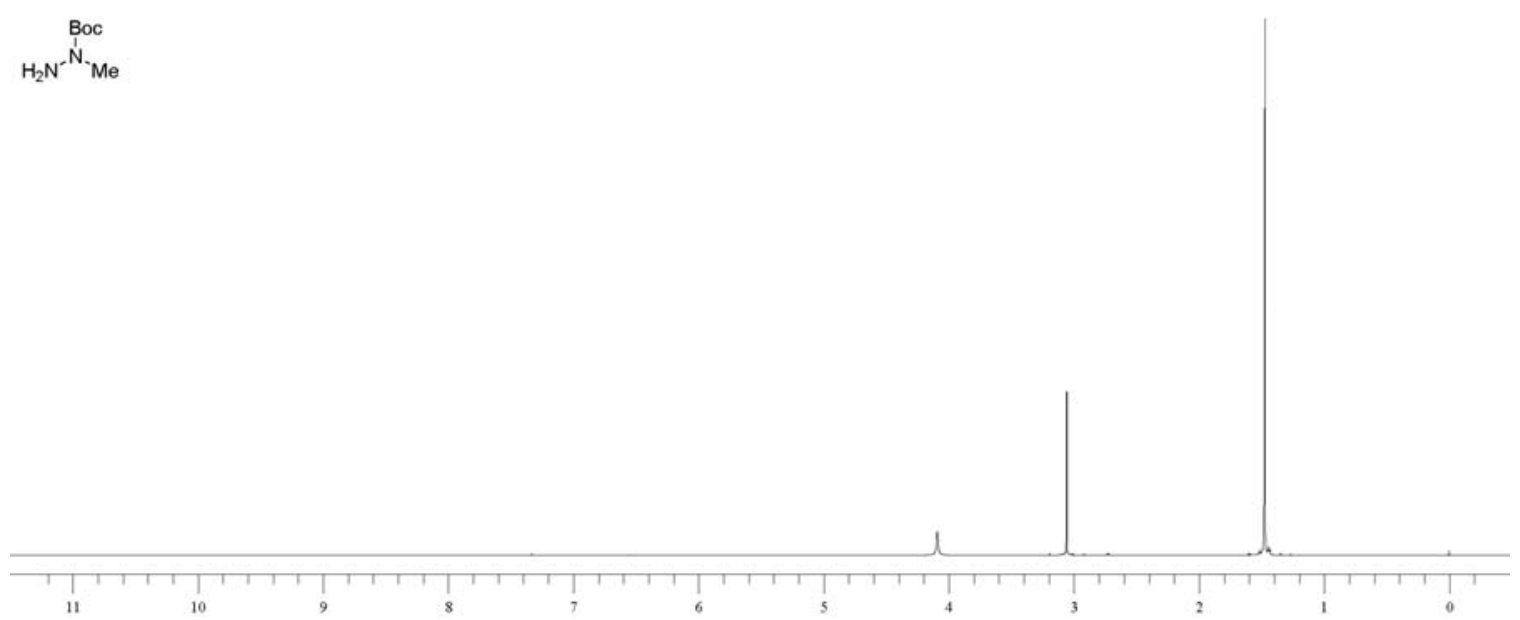

Ethyl 6-(2-(tert-Butoxycarbonyl)-2-methylhydrazinyl)-1,2,4-triazine-5-carboxylate (10).
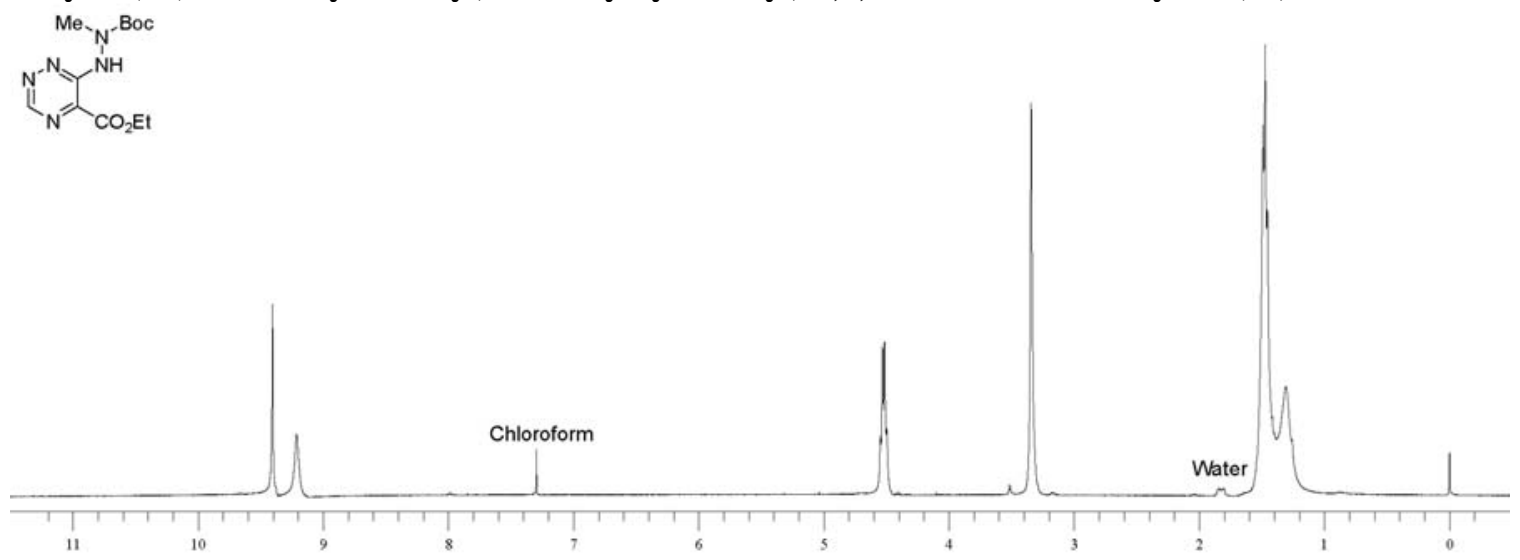
1,2-Dihydro-2-methyl-3H-pyrazolo[4,3-e][1,2,4]triazin-3-one (11).
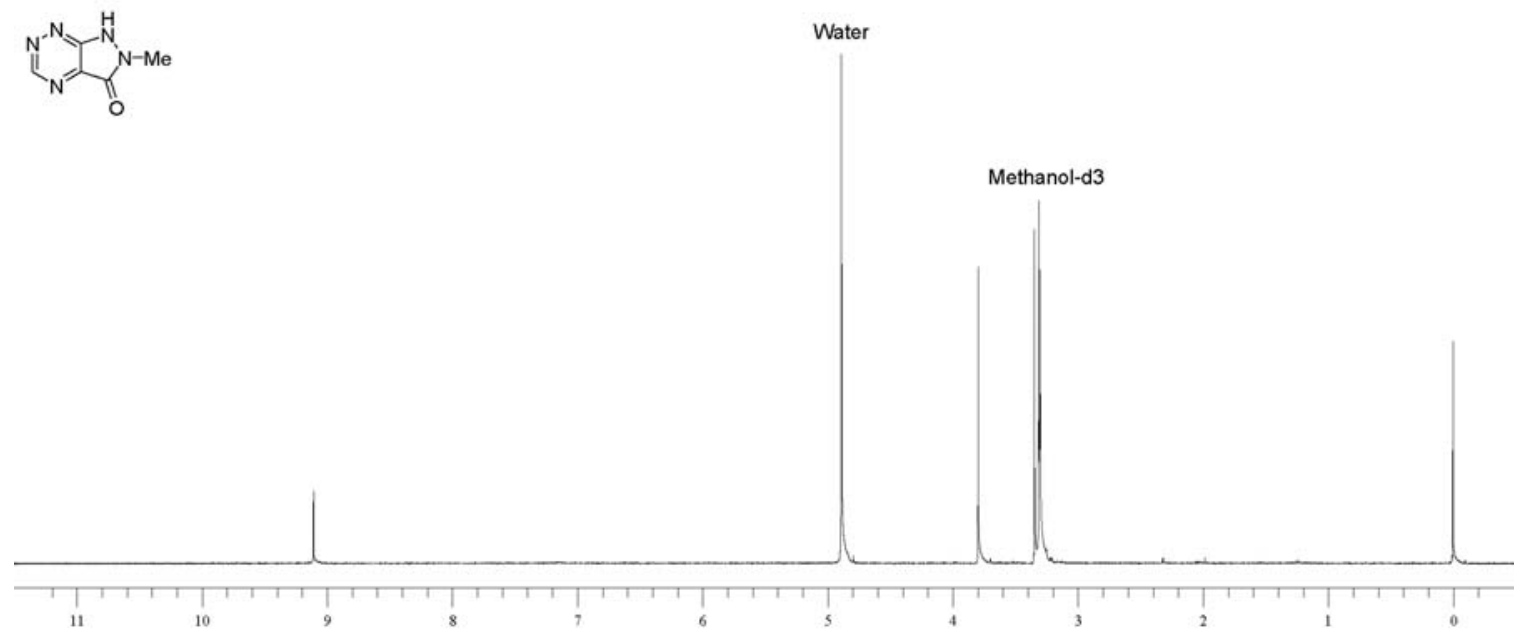

3-Methoxy-2-methyl-2H-pyrazolo[4,3-e][1,2,4]triazine (12).

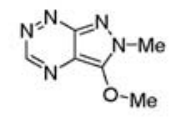

Vater

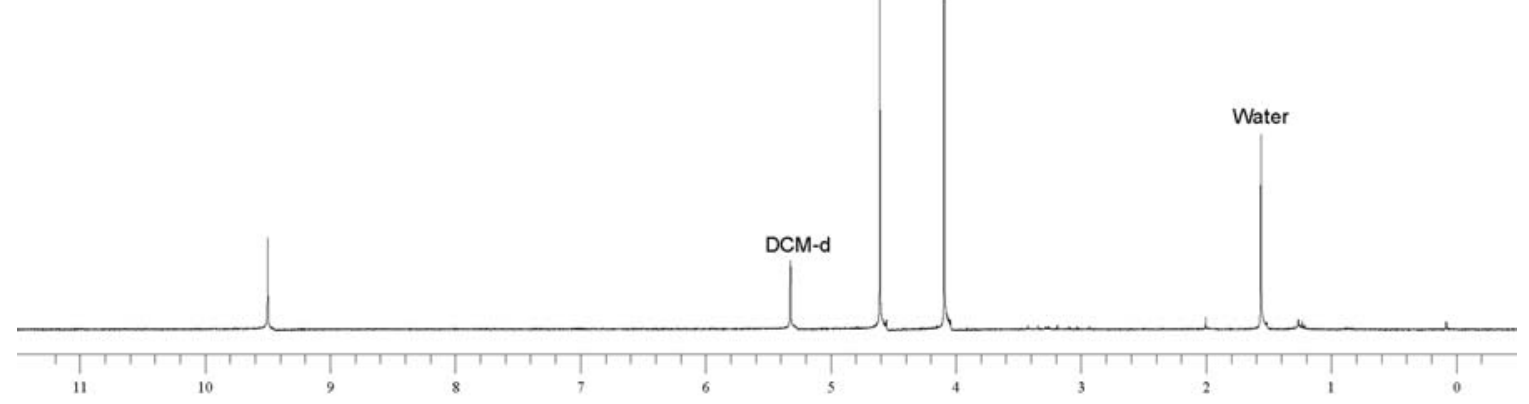

Ethyl 6-(2-(tert-Butoxycarbonyl)hydrazinyl)-1,2,4-triazine-5-carboxylate (14).

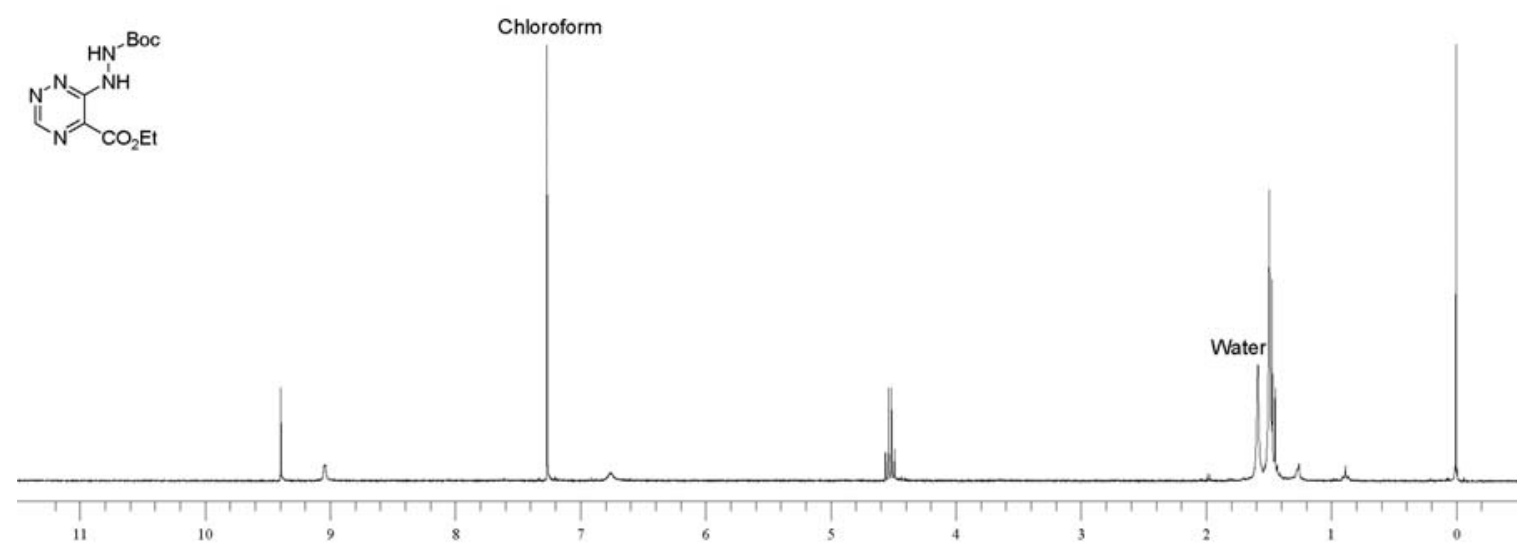


1,2-Dihydro-3H-Pyrazolo[4,3-e][1,2,4]triazin-3-one (15).
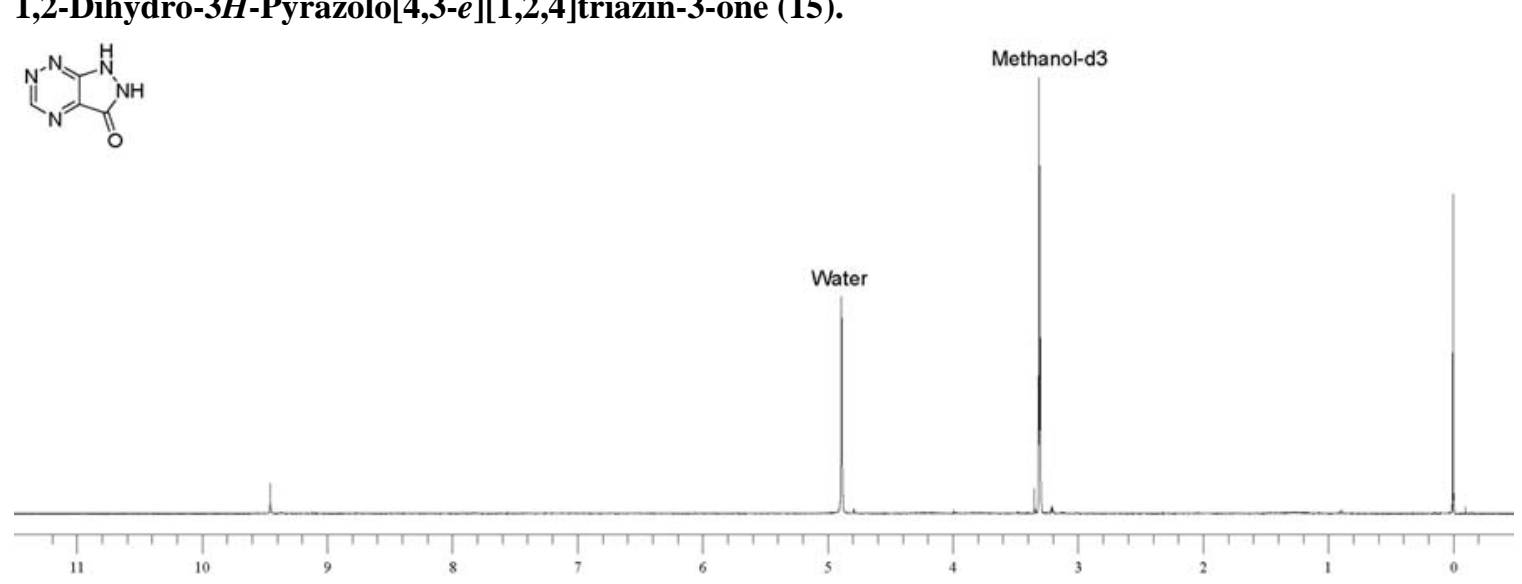

Nostocine A (2).
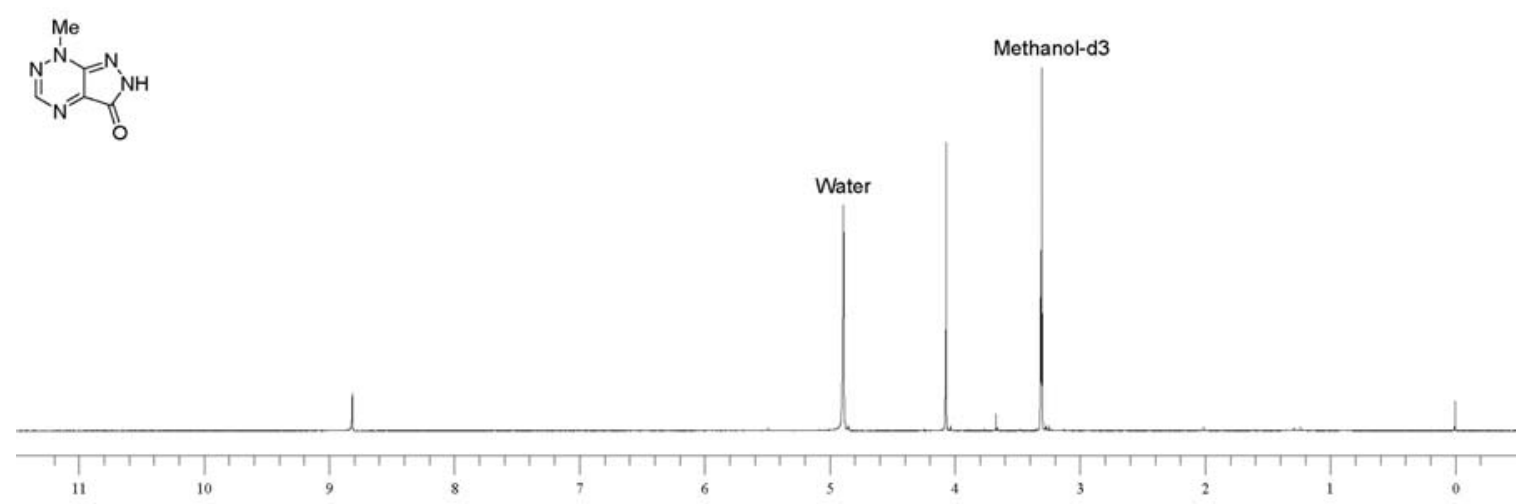


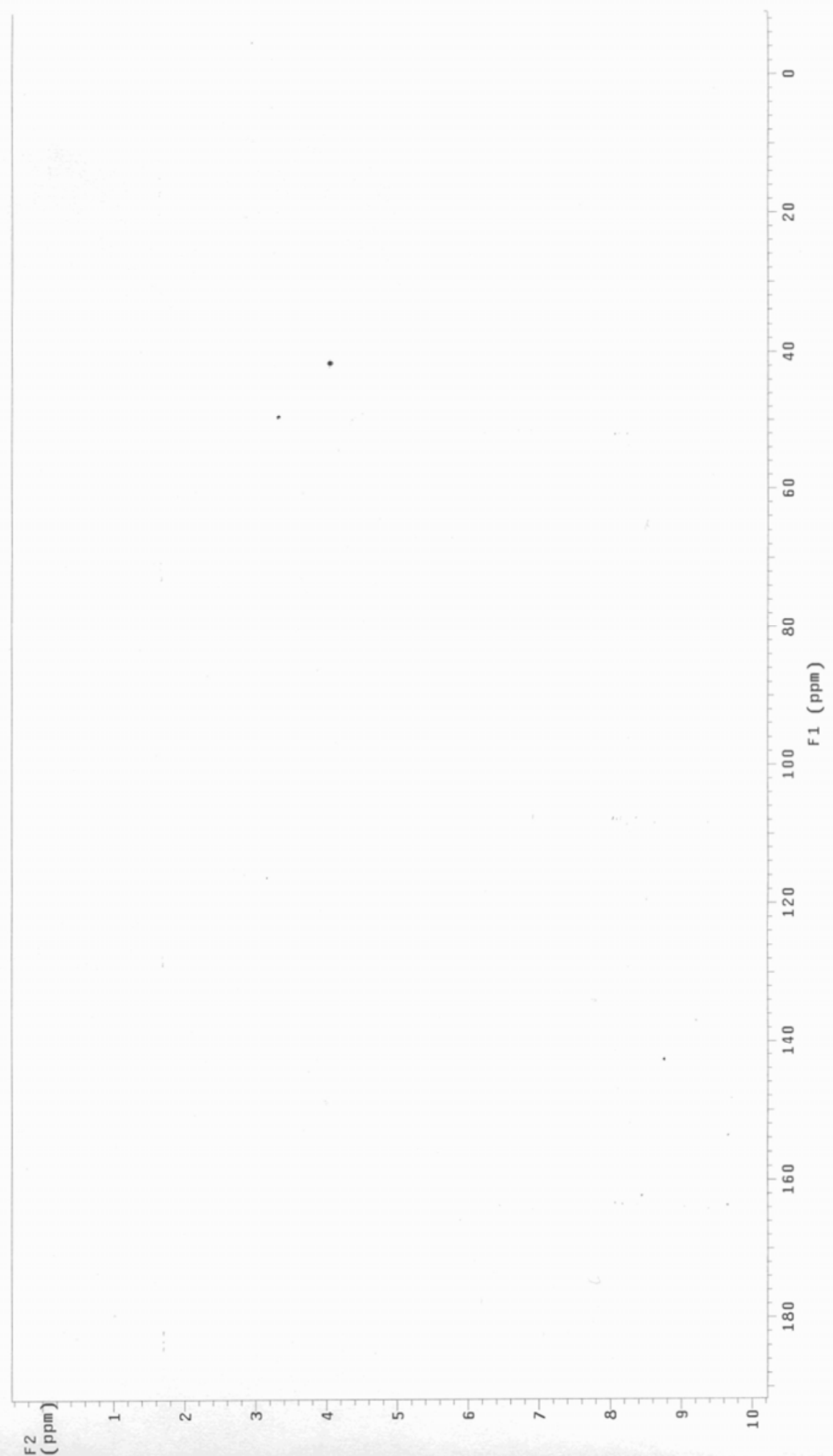

Figure 1. HMQC Data for 2.

Reproduction of the hmqc spectrum of 2 recorded on a Varian Unity INOVIA 500 MHz. The following key correlations are observed: ${ }^{1} \mathrm{H}(@ 4.04) \rightarrow{ }^{13} \mathrm{C}(@ 41.5) ;{ }^{1} \mathrm{H}(@ 8.76) \rightarrow{ }^{13} \mathrm{C}(142.7)$. This is consistent with the reported ${ }^{13}$ coupled carbon spectrum: ${ }^{13} \mathrm{C}$ NMR (100 MHz, $\left.\mathrm{CD}_{3} \mathrm{OD}, \delta\right): 42.3$ (q), 139.4 (s), 143.5 (d), $155.4(\mathrm{~s}), 161.8(\mathrm{~s})$. 


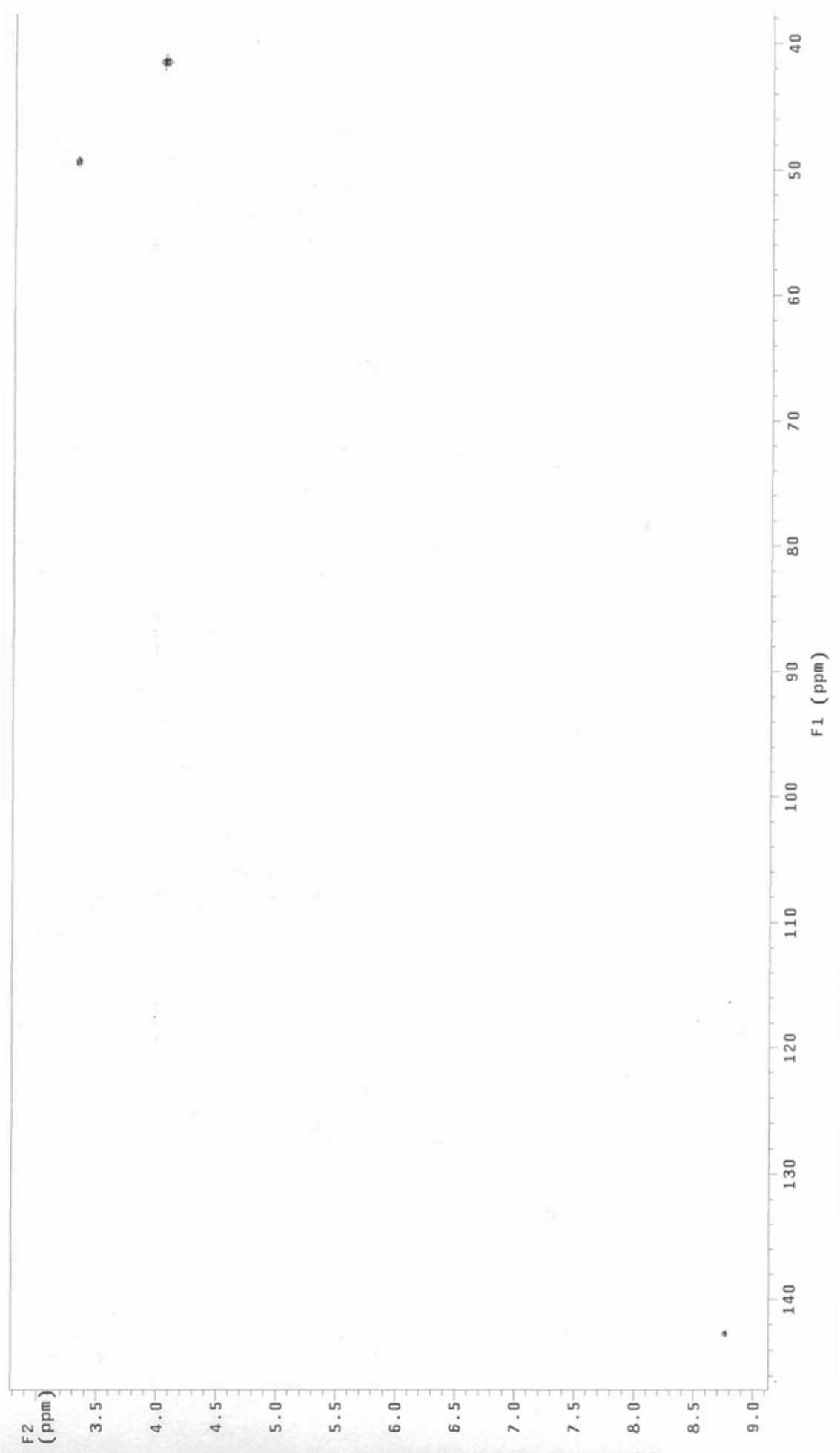

Figure 2. HMQC Data for 2 (Expansion).

Reproduction of the hmqc spectrum of $\mathbf{2}$ recorded on a Varian Unity INOVIA $500 \mathrm{MHz}$. The following key correlations are observed: ${ }^{1} \mathrm{H}(@ 4.04) \rightarrow{ }^{13} \mathrm{C}(@ 41.5) ;{ }^{1} \mathrm{H}(@ 8.76) \rightarrow{ }^{13} \mathrm{C}(@ 142.7)$. This is consistent with the reported ${ }^{13}$ coupled carbon spectrum: ${ }^{13} \mathrm{C}$ NMR (100 MHz, $\left.\mathrm{CD}_{3} \mathrm{OD}, \delta\right): 42.3$ (q), 139.4 (s), 143.5 (d), $155.4(\mathrm{~s}), 161.8(\mathrm{~s})$. 


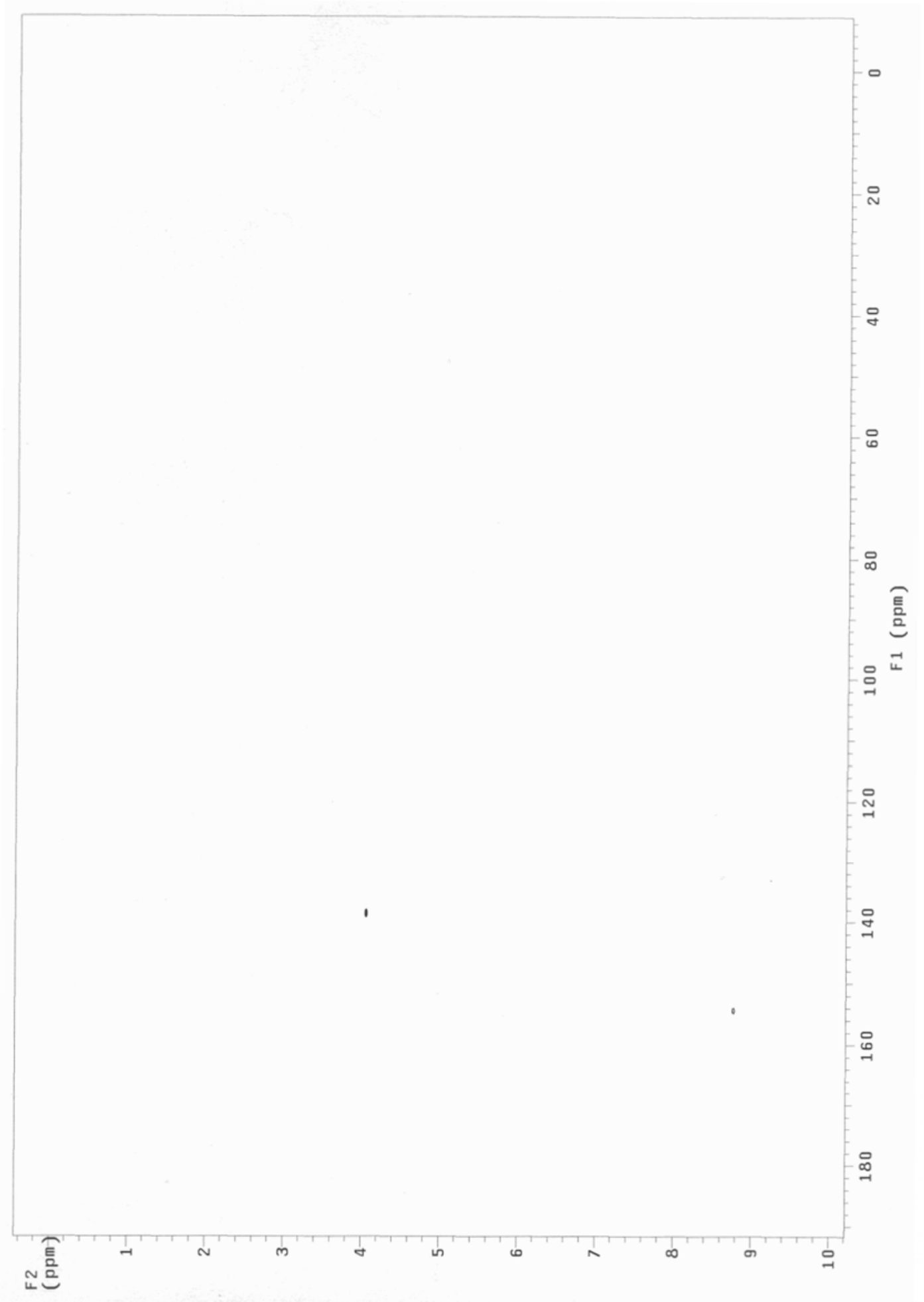

Figure 3. HMBC Data for 2.

Reproduction of the gHMBC spectrum of 2 recorded on a Varian Unity INOVIA $500 \mathrm{MHz}$. The following key correlations are observed: ${ }^{1} \mathrm{H}(@ 4.04) \rightarrow{ }^{13} \mathrm{C}(@ 138.6) ;{ }^{1} \mathrm{H}(@ 8.76) \rightarrow{ }^{13} \mathrm{C}(@ 154.6)$. This is consistent with the reported ${ }^{13} \mathrm{HMBC}$ spectrum: ${ }^{1} \mathrm{H}(@ 4.02) \rightarrow{ }^{13} \mathrm{C}(@ 139.4) ;{ }^{1} \mathrm{H}(@ 8.74) \rightarrow{ }^{13} \mathrm{C}(@ 155.4)$. 


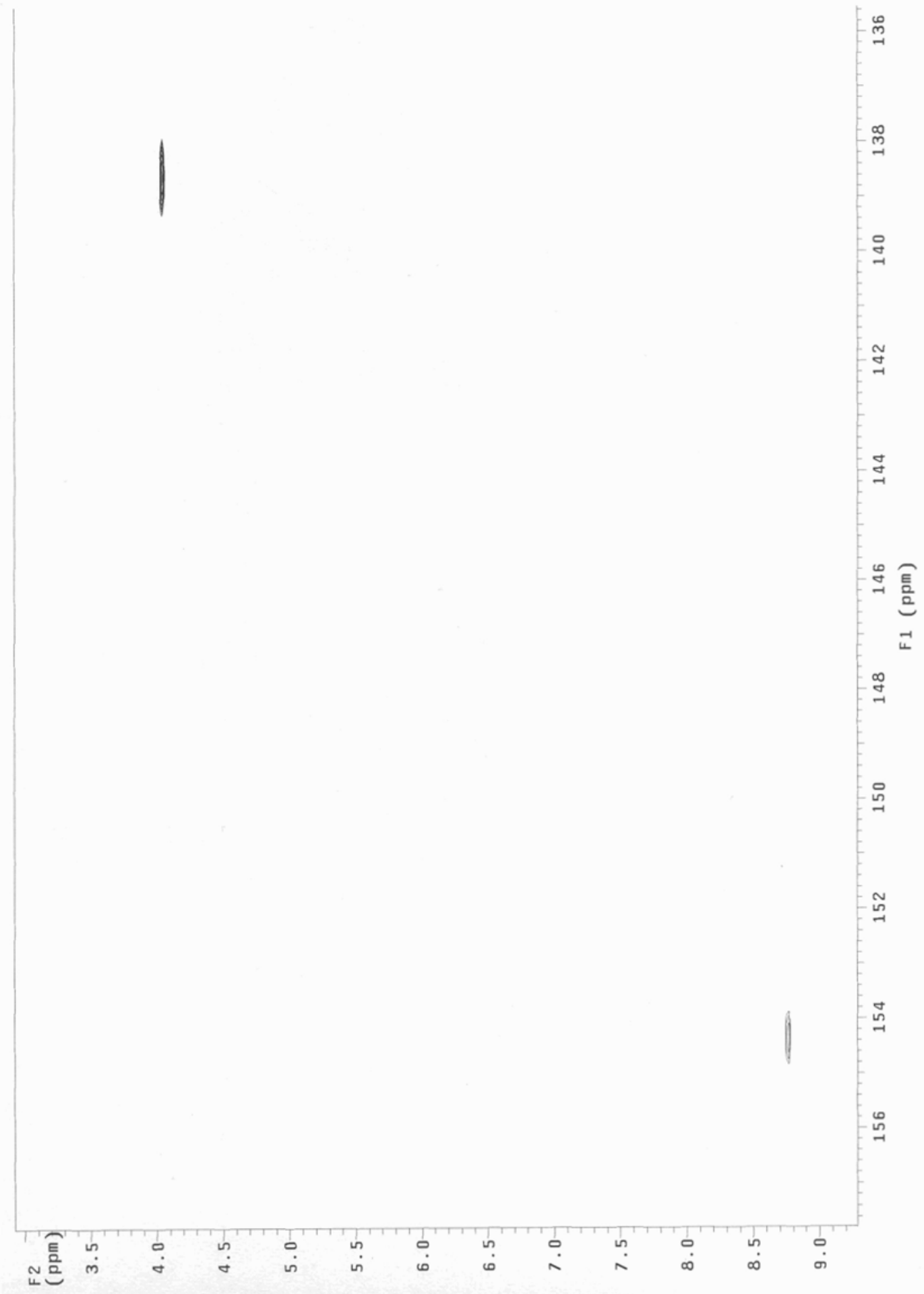

Figure 4. HMBC Data for 2 (Expansion).

Reproduction of the gHMBC spectrum of 2 recorded on a Varian Unity INOVIA $500 \mathrm{MHz}$. The following key correlations are observed: ${ }^{1} \mathrm{H}(@ 4.04) \rightarrow{ }^{13} \mathrm{C}(138.6) ;{ }^{1} \mathrm{H}(@ 8.76) \rightarrow{ }^{13} \mathrm{C}(@ 154.6)$. This is consistent with the reported ${ }^{13} \mathrm{HMBC}$ spectrum: ${ }^{1} \mathrm{H}(@ 4.02) \rightarrow{ }^{13} \mathrm{C}(@ 139.4) ;{ }^{1} \mathrm{H}(@ 8.74) \rightarrow{ }^{13} \mathrm{C}(@ 155.4)$. 
Fluviol A (3).

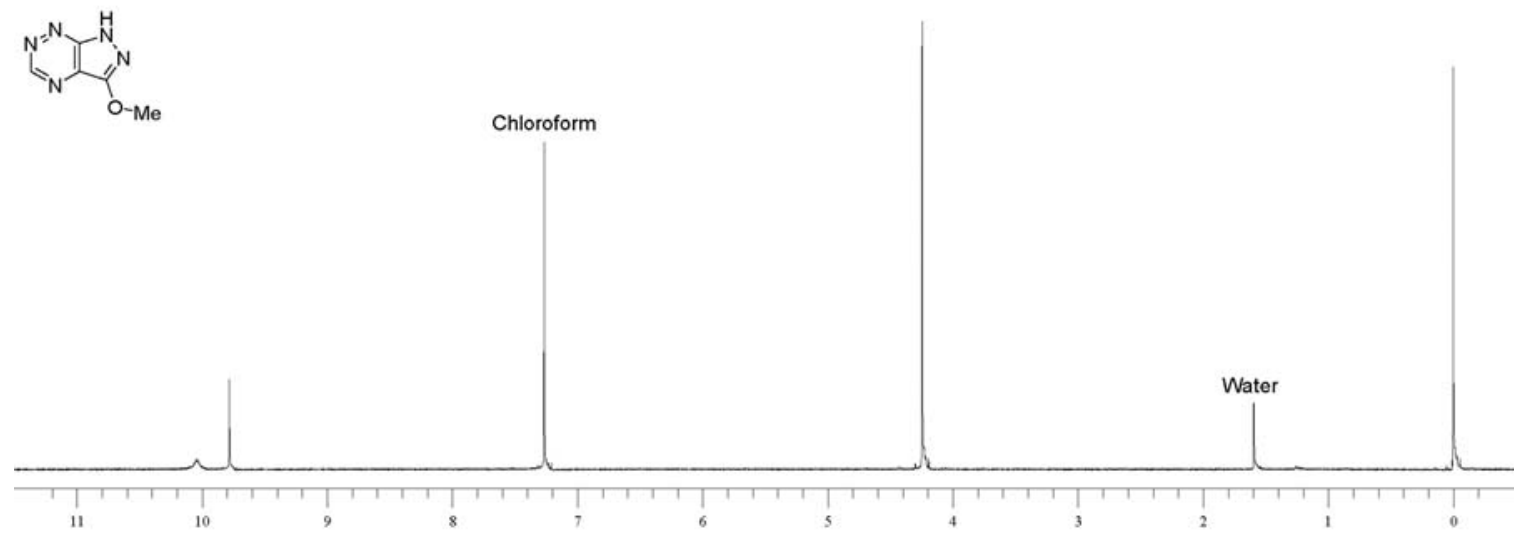

Pseudoiodinine (19).
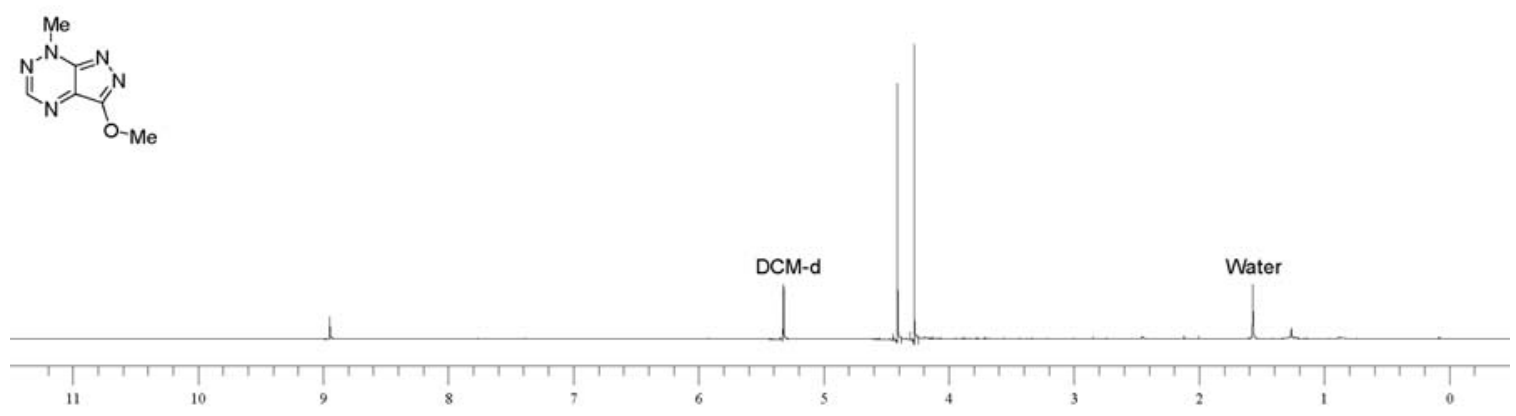


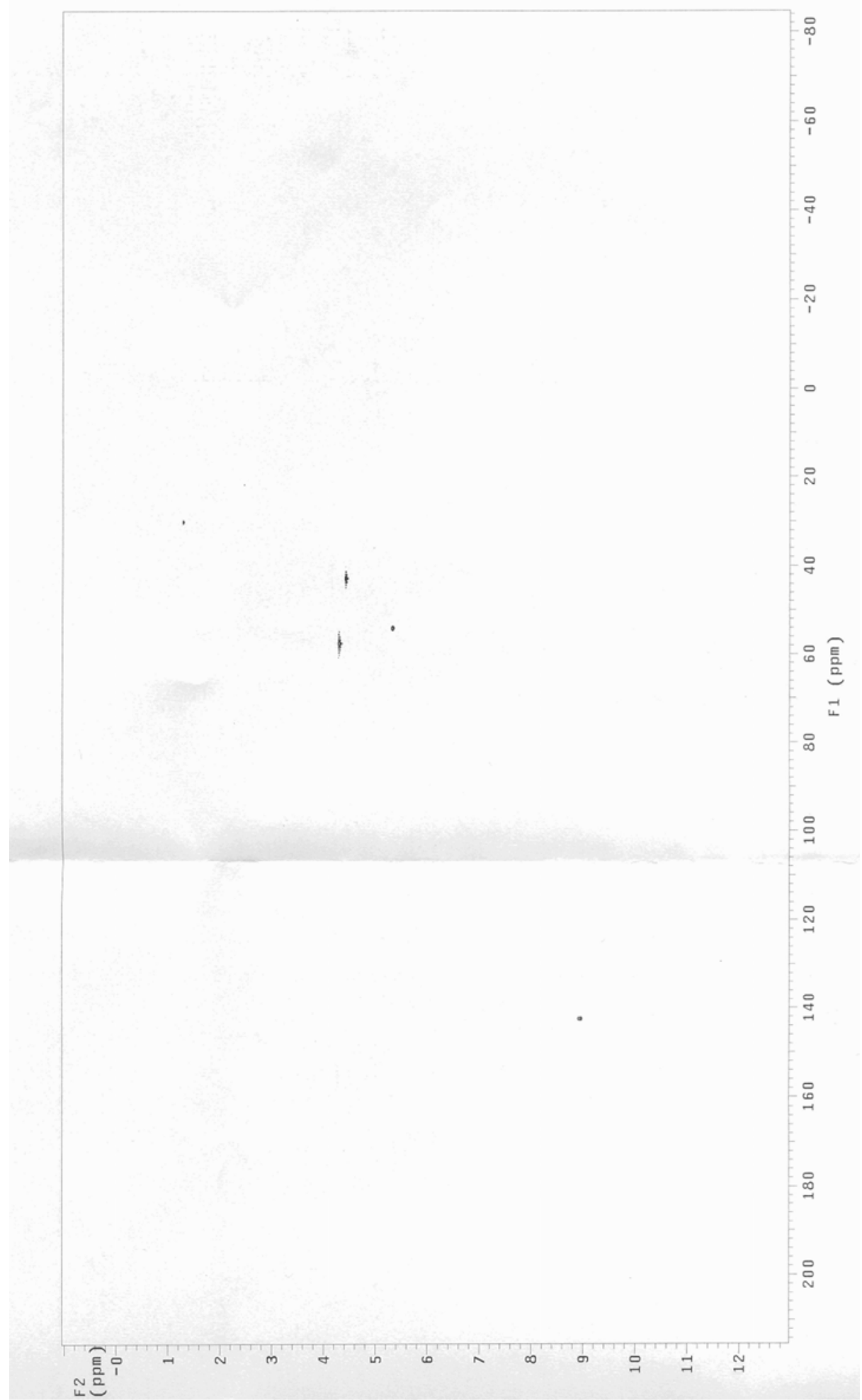

Figure 5. HMQC Data for 19.

Reproduction of the hmqc spectrum of $\mathbf{1 9}$ recorded on a Varian Unity INOVIA $500 \mathrm{MHz}$ spectrometer with temperature control set to $-30^{\circ} \mathrm{C}$ to minimize decomposition to fluviol A. The following key correlations are observed: ${ }^{1} \mathrm{H}(@ 4.27) \rightarrow{ }^{13} \mathrm{C}(@ 57.6) ;{ }^{1} \mathrm{H}(@ 4.41) \rightarrow{ }^{13} \mathrm{C}(@ 43.0) ;{ }^{1} \mathrm{H}(@ 8.95) \rightarrow{ }^{13} \mathrm{C}(@ 142.6)$. 


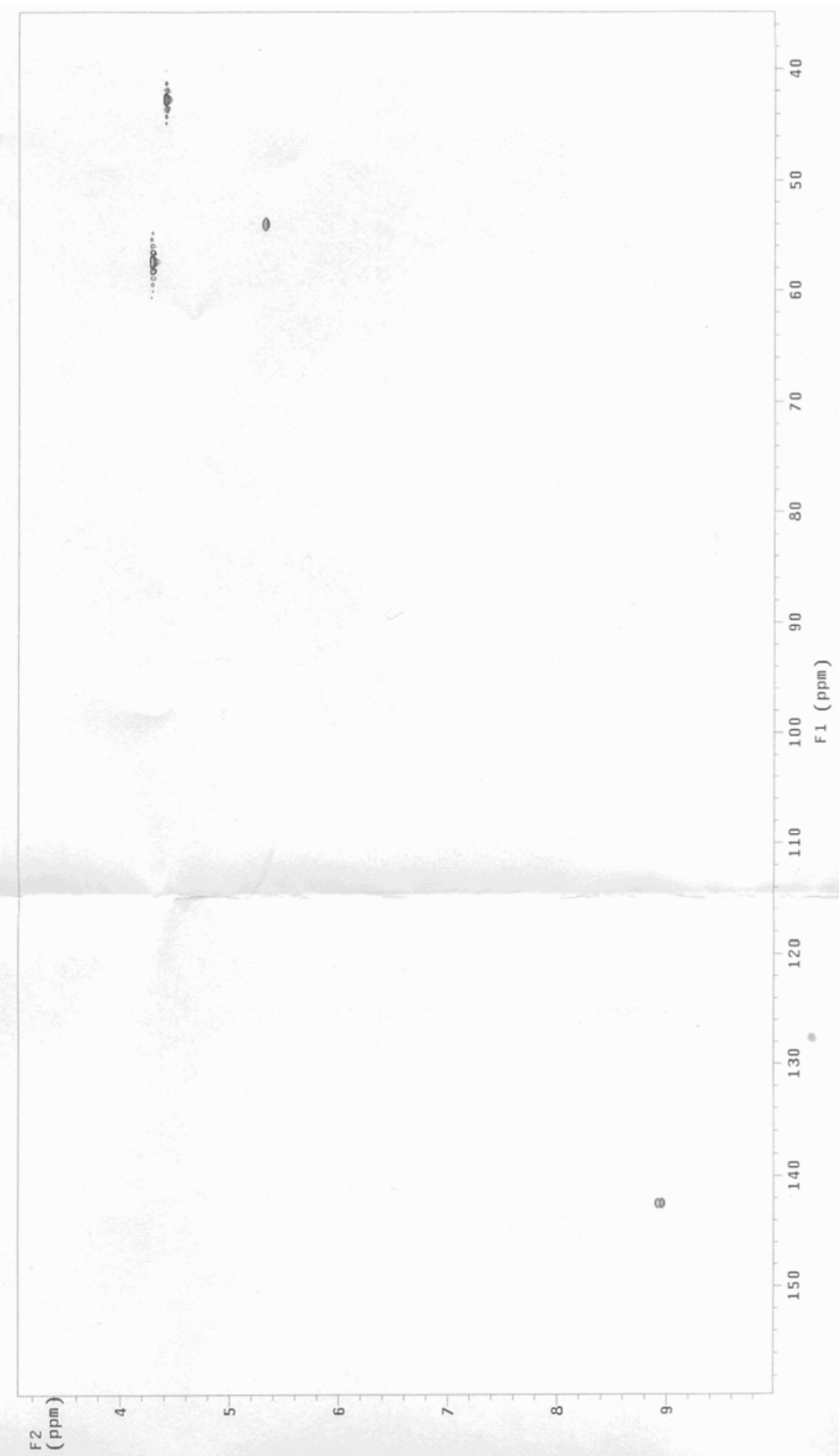

Figure 6. HMQC Data for 19 (Expansion).

Reproduction of the hmqc spectrum of $\mathbf{1 9}$ recorded on a Varian Unity INOVIA $500 \mathrm{MHz}$ spectrometer with temperature control set to $-30^{\circ} \mathrm{C}$ to minimize decomposition to fluviol A. The following key correlations are observed: ${ }^{1} \mathrm{H}(@ 4.27) \rightarrow{ }^{13} \mathrm{C}(@ 57.6) ;{ }^{1} \mathrm{H}(@ 4.41) \rightarrow{ }^{13} \mathrm{C}(@ 43.0) ;{ }^{1} \mathrm{H}(@ 8.95) \rightarrow{ }^{13} \mathrm{C}(142.6)$. 


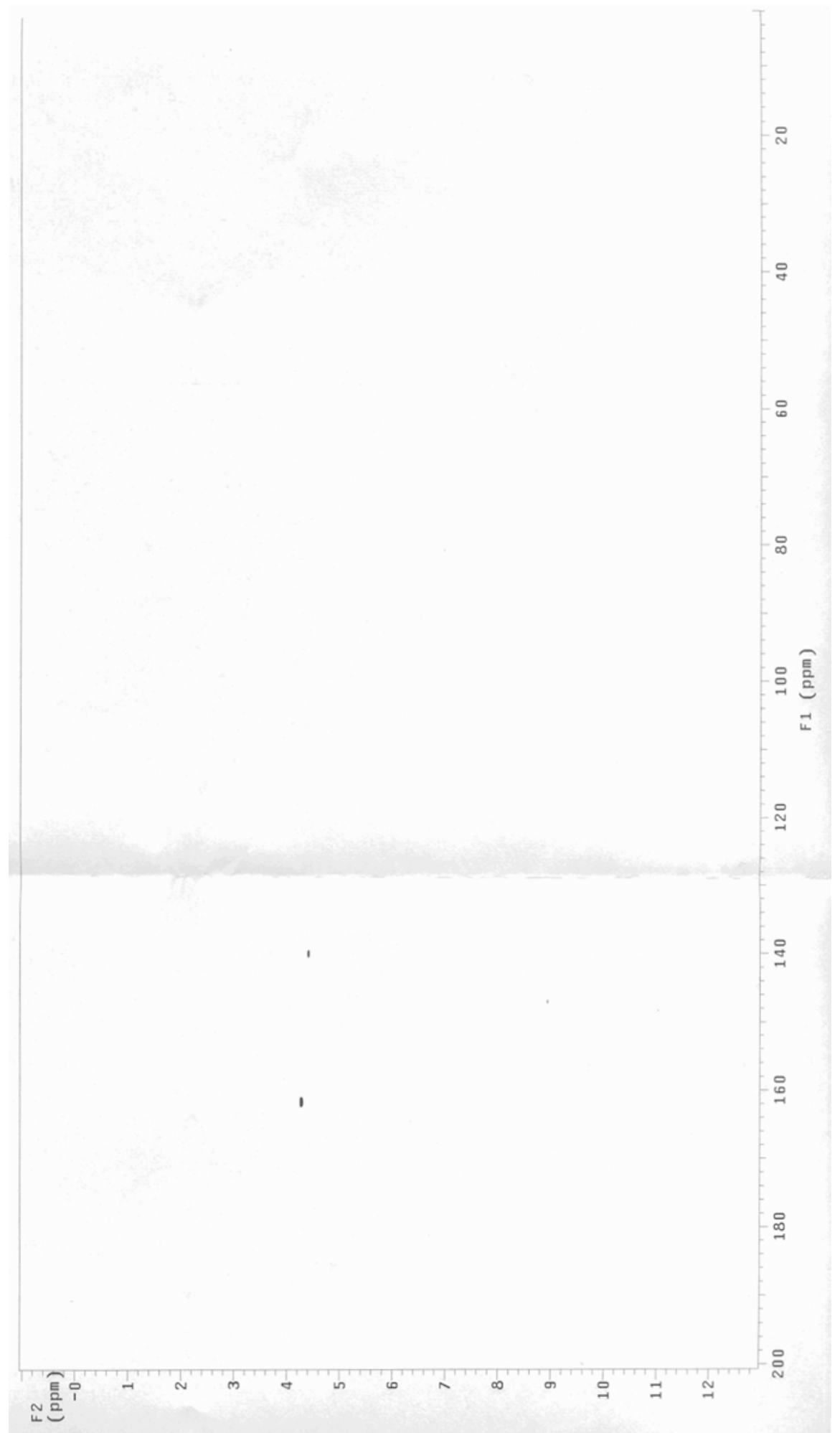

Figure 7. HMBC Data for 19.

Reproduction of the gHMBC spectrum of 19 recorded on a Varian Unity INOVIA $500 \mathrm{MHz}$ spectrometer with temperature control set to $-30^{\circ} \mathrm{C}$ to minimize decomposition to fluviol A. The following correlations are observed: ${ }^{1} \mathrm{H}(@ 4.27) \rightarrow{ }^{13} \mathrm{C}(@ 160.7) ;{ }^{1} \mathrm{H}(@ 4.41) \rightarrow{ }^{13} \mathrm{C}(@ 139.0)$;

${ }^{1} \mathrm{H}(@ 8.95) \rightarrow{ }^{13} \mathrm{C}(@ 146.0)$ 


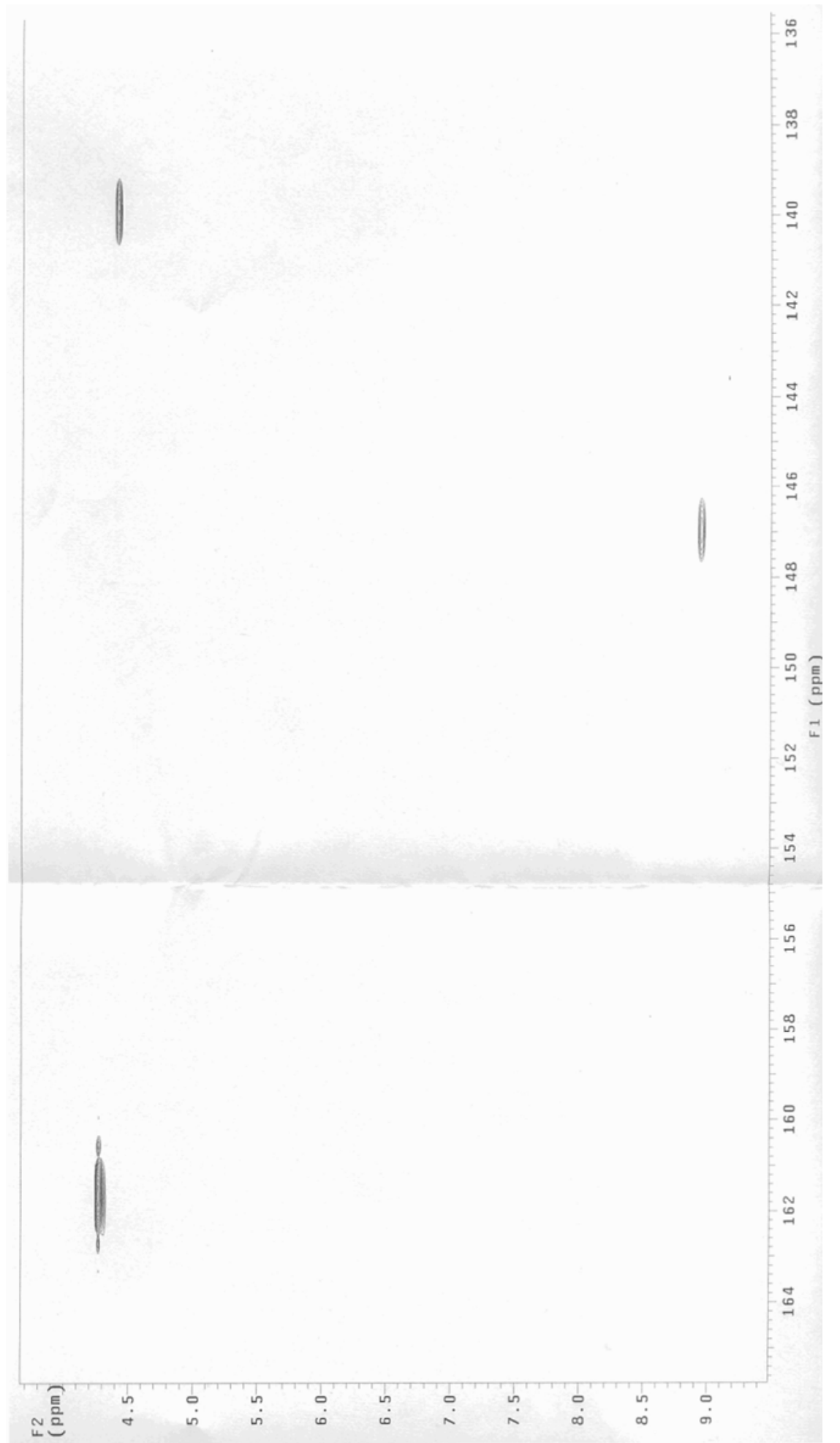

Figure 8. HMBC Data for 19 (Expansion).

Reproduction of the gHMBC spectrum of 19 recorded on a Varian Unity INOVIA $500 \mathrm{MHz}$ spectrometer with temperature control set to $-30{ }^{\circ} \mathrm{C}$ to minimize decomposition to fluviol A. The following correlations are observed: ${ }^{1} \mathrm{H}(@ 4.27) \rightarrow{ }^{13} \mathrm{C}(@ 160.7) ;{ }^{1} \mathrm{H}(@ 4.41) \rightarrow{ }^{13} \mathrm{C}(@ 139.0)$;

${ }^{1} \mathrm{H}(@ 8.95) \rightarrow{ }^{13} \mathrm{C}(@ 146.0)$ 
1,2-Dihydro-1-methyl-3H-pyrazolo[4,3-e][1,2,4]triazin-3-one (21).
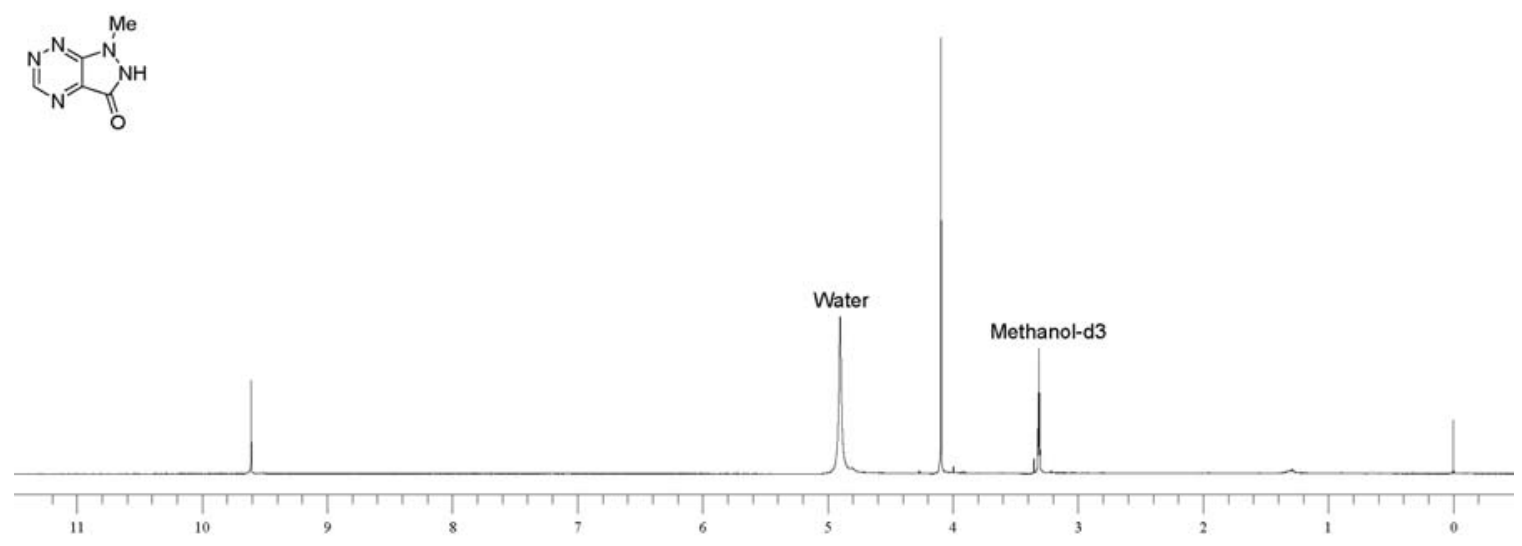

3-Methoxy-1-methyl-1H-pyrazolo[4,3-e][1,2,4]triazine (20).
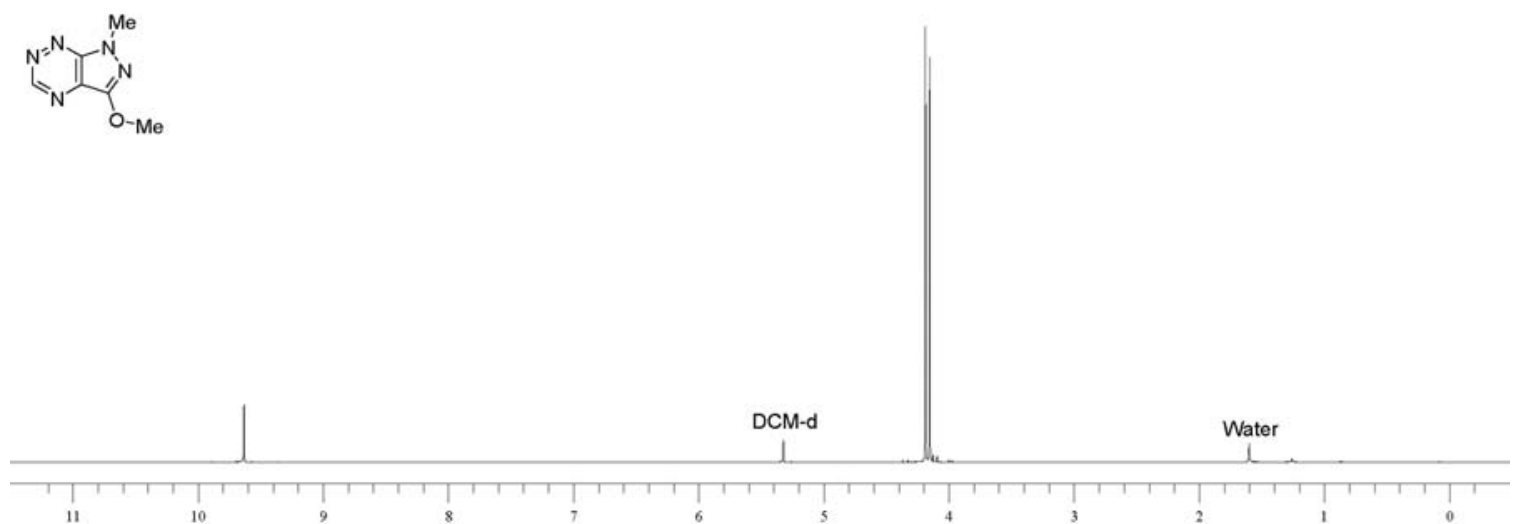
1,2-Dihydro-1,2-dimethyl-3H-pyrazolo[4,3-e][1,2,4]triazin-3-one (22).
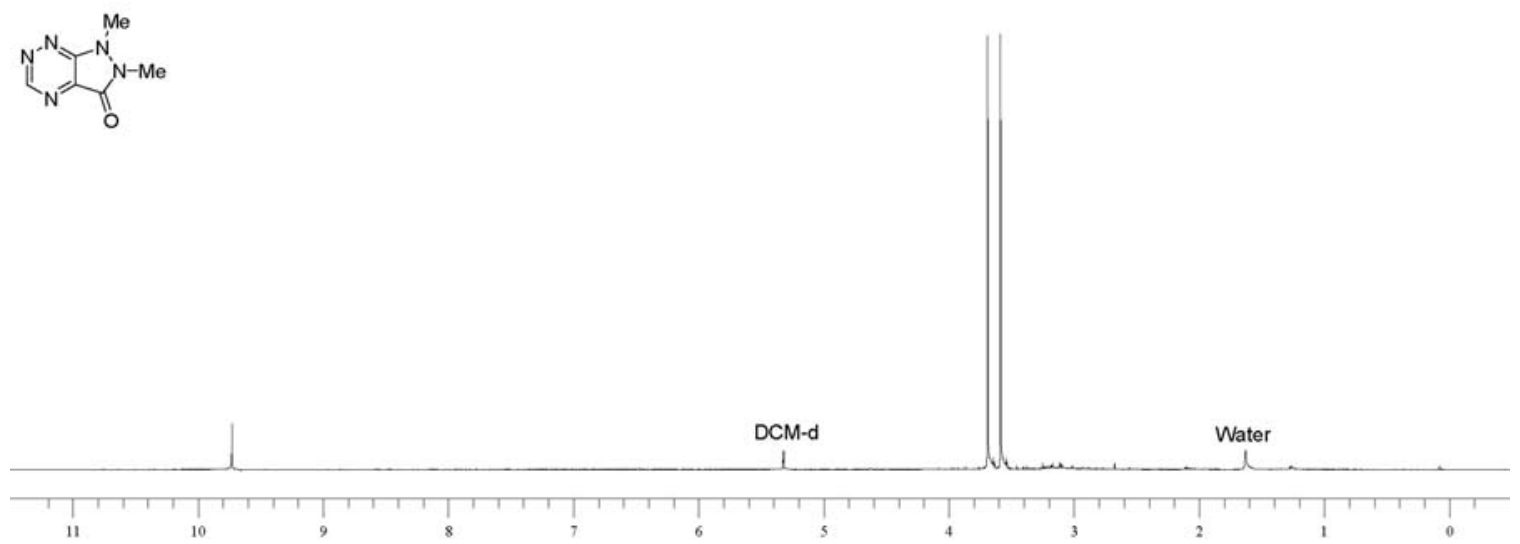

2,7-Dihydro-2,7-dimethyl-3H-pyrazolo[4,3-e][1,2,4]triazin-3-one (23).
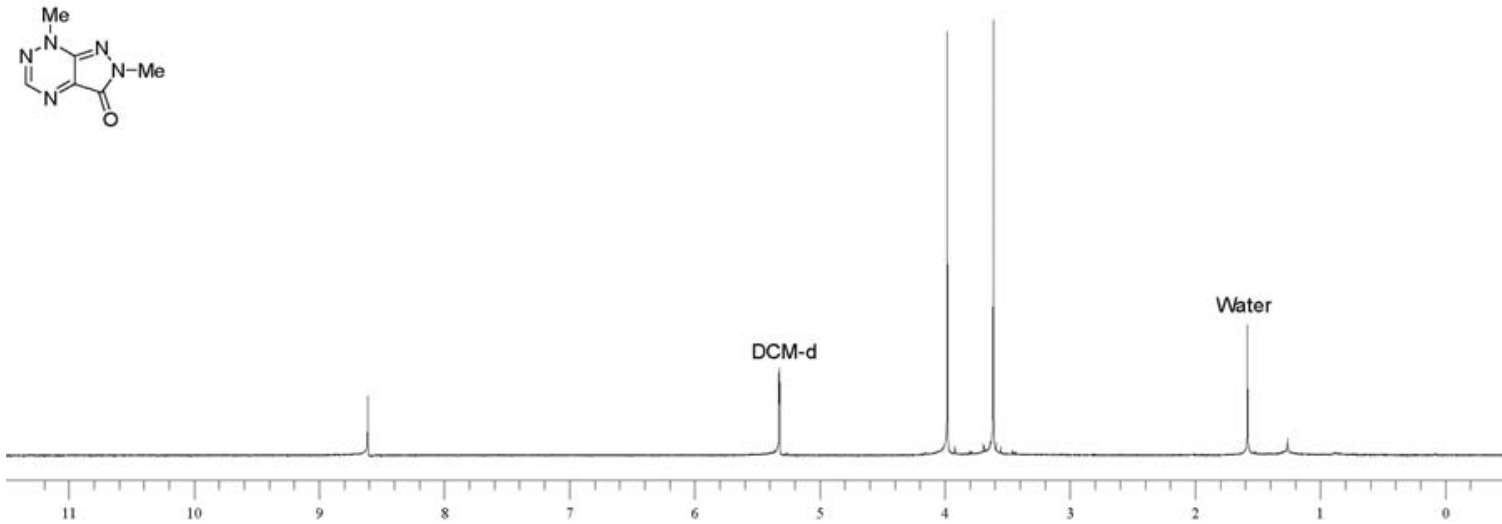